\title{
De covid-19-maatregelen van de EU: buigen of barsten?
}

\author{
Mr. drs. H.A.G. Temmink*
}

\begin{abstract}
Sinds het uitbreken van de covid-19-crisis heeft de Europese Unie zich schrap gezet om de gevolgen van de pandemie te beteugelen. Deze bijdrage geeft een overzicht van de initiatieven die tot dusverre zijn genomen. In eerste instantie betreft het maatregelen om de directe gevolgen voor de volksgezondheid te bestrijden en de integriteit van de interne markt te maarborgen. Ondertussen wordt ook aan herstelmaatregelen gemerkt voor het weer aan de gang krijgen van de economie. Wat zijn de gevolgen van corona voor de interne markt en de toekomst van de Unie?
\end{abstract}

\section{Inleiding}

De Europese Unie (EU) staat sinds het begin van de coronacrisis voor ongekende uitdagingen. Waar de mondiale crisis om een grensoverschrijdende aanpak vraagt, namen veel landen vooral maatregelen om hun eigen burgers en ondernemingen te beschermen. Grenzen werden gesloten, markten afgeschermd en het nationale bedrijfsleven kan rekenen op forse financiële steun.

$\mathrm{Na}$ een moeizame periode begint de reactie van de EU op covid-19 en de onvermijdelijke economische recessie meer vorm te krijgen. Enerzijds blijven de prioriteiten gericht op de volksgezondheid: het beperken van de verspreiding van het virus; het beschikbaar stellen van noodhulp waaronder medische uitrustingen; het bevorderen van onderzoek naar de behandelingen en vaccins. Anderzijds tracht de EU het vrije verkeer en een 'gelijk speelveld' voor ondernemingen binnen de interne markt zo goed mogelijk te garanderen en worden economische en financiële maatregelen genomen om lidstaten, bedrijven en de economie in het algemeen te ondersteunen.

De Wereldgezondheidsorganisatie (WHO) heeft de uitbraak van covid-19 op 30 januari 2020 aangemerkt als 'noodsituatie op het gebied van de volksgezondheid van

Mr. drs. H.A.G. (Harrie) Temmink is plv. afdelingshoofd van de unit 'Intellectuele Eigendom', DG GROW, Europese Commissie. Deze bijdrage is op strikt persoonlijke titel geschreven. internationaal belang' en op 11 maart als een pandemie. Reeds op 13 maart presenteerde de Europese Commissie haar eerste mededeling over een gecoördineerde economische respons op de uitbraak van covid-19. ${ }^{1}$ Op 17 april drong het Europees Parlement (EP) aan op een gecoördineerde Europese respons, ook na de lockdomn. ${ }^{2}$ Vervolgens hebben op 15 april de voorzitters van de Europese Commissie en de Europese Raad een gezamenlijk Europees stappenplan gepresenteerd voor de opheffing van de crisismaatregelen en het bestrijden van de negatieve economische gevolgen. ${ }^{3}$ Op 27 mei heeft de Commissie, op uitnodiging van de Raad en het EP, een volgende stap gezet met voorstellen voor een grootscheeps herstelpakket. $^{4}$

Deze bijdrage biedt een overzicht van de EU-maatregelen om de coronacrisis te bestrijden (stand van zaken tot 11 juni). Eerst wordt ingegaan op de bevoegdheden van de Unie op het gebied van de volksgezondheid en de initiatieven om de verspreiding van het covid-19-virus aan te pakken. Daarna komen de maatregelen aan bod die de EU heeft genomen om de integriteit van de interne markt (het vrije verkeer goederen, grenscontroles en een onvervalst mededingingsregime) te waarborgen. Vervolgens worden de economische en financiële maatregelen om de crisis het hoofd te bieden in kaart gebracht. Tot slot wordt met een aantal beschouwende opmerkingen de voorlopige balans opgemaakt.

Deze bijdrage is ruim maar niet uitputtend. Voor een volledig overzicht wordt verwezen naar specifieke web-

1. Gecoördineerde economische respons op de uitbraak van covid-19, $\operatorname{COM}(2020) 112$ final.

2. Zie de resolutie van het Europees Parlement betreffende gecoördineerde EU-maatregelen om de covid-19-pandemie en de gevolgen ervan te bestrijden (2020/2616(RSP), www.europarl.europa.eu/doceo/ document/TA-9-2020-0054_NL.html.

3. Gezamenlijk Europees stappenplan voor de opheffing van de inperkingsmaatregelen in verband met COVID 19, PbEU 2020, C 126 (hierna: 'het stappenplan').

4. Mededeling 'Het moment van Europa: herstel en voorbereiding voor de volgende generatie', COM (2020) 456 def van 27 mei 2020 (hierna: 'het herstelplan'). Zie https://ec.europa.eu/commission/presscorner/ detail/nl/ip_20_940. 
sites van de Europese Commissie, ${ }^{5}$ de Europese Raad en de Raad van de EU, ${ }^{6}$ het Europees Parlement, ${ }^{7}$ EURLex $^{8}$ en nationale instanties. ${ }^{9}$

\section{Maatregelen op het gebied van de volksgezondheid}

\section{Bevoegdheden van de EU}

De covid-19-pandemie is eerst en vooral een gezondheidscrisis. In hoeverre is de EU bevoegd maatregelen te nemen die de volksgezondheid betreffen?

Volgens het attributiebeginsel kan de EU uitsluitend handelen binnen de grenzen van de bevoegdheden die in de EU-Verdragen zijn vastgelegd (art. 5 lid 2 Verdrag betreffende de Europese Unie (VEU)). Artikel 168 Verdrag betreffende werking van de Europese Unie (VWEU) biedt het kader voor het handelen op het gebied van de volksgezondheid. Het optreden van de $\mathrm{EU}$ is onder meer gericht op de bestrijding van grote bedreigingen van de volksgezondheid; het bevorderen van onderzoek naar de oorzaken, de overdracht en de preventie daarvan, het bevorderen van gezondheidsvoorlichting alsmede 'de controle van, de alarmering bij en de bestrijding van ernstige grensoverschrijdende bedreigingen van de gezondheid' (art. 168 lid 1 VWEU). Er kan geen twijfel over bestaan dat alle denkbare facetten van beleid om het covid-19-virus tegen te gaan tot de bevoegdheden van de EU behoren.

De beginselen van subsidiariteit en evenredigheid indachtig (art. 5 lid 2 en $3 \mathrm{VEU}$ ) is het optreden van de EU op het gebied van de volksgezondheid echter op twee manieren beperkt. Ten eerste vormen de maatregelen van de Unie een ondersteuning en aanvulling op het nationale beleid. De Unie moedigt samenwerking tussen de lidstaten aan en de Europese Commissie kan alle 'dienstige initiatieven nemen om de onderlinge coördinatie tussen de lidstaten te bevorderen'. Het primaat van het volksgezondheidsbeleid ligt dus duidelijk bij de lidstaten. Ten tweede zijn de EU-handelingen op de genoemde gebieden beperkt tot stimuleringsmaatregelen en is harmonisatie van nationale regelgeving niet toegestaan. ${ }^{10}$ Tijdens de coronacrisis wordt veelvuldig gebruikgemaakt van het instrument van de 'aanbeve-

5. https://ec.europa.eu/info/live-work-travel-eu/health/coronavirus response_nl. Zie voor gedetailleerde data over covid-19 de specifieke website van Eurostat, https://ec.europa.eu/eurostat/web/covid-19.

6. www.consilium.europa.eu/nl/topics/covid-19/.

7. www.europarl.europa.eu/news/nl/headlines/priorities/de-repons-vande-eu-op-het-coronavirus.

8. Een overzicht van in het Publicatieblad gepubliceerde covid-19 documenten is te vinden onder https://eur-lex.europa.eu/content/news/ index.html? locale $=$ nl.

9. Zie bijvoorbeeld Europa Nu, www.europa-nu.nl/id/vl6veni6cpys/ europese_maatregelen_coronacrisis en ECER https://ecer.minbuza.nl/ $\mathrm{nl} /$-/covid-19-eu-ontwikkelingen-corona-virus? redirect $=\% 2 \mathrm{Fnl}$ $\% 2$ Fecer.

10. Zie ook art. 2 lid 5 VWEU. Juridisch bindende handelingen zijn slechts in bepaalde specifiek omschreven omstandigheden geoorloofd om 'gemeenschappelijke veiligheidskwesties' het hoofd te bieden (art. 168 lid 4 VWEU). ling', een niet-bindende handeling ex artikel 192 VWEU, en van 'richtsnoeren' die vaak (maar niet altijd) in de vorm van 'mededelingen van de Commissie' worden uitgevaardigd.

In de nasleep van eerdere uitbraken van besmettelijke ziektes zoals de Mexicaanse griep, sars en het ebolavirus heeft de EU al regelmatig gebruikgemaakt van deze bevoegdheden. Het kader voor de coördinatie van nationale en EU-acties vormt Besluit 1082/2013/EU van het EP en de Raad. ${ }^{11}$ Dit besluit bevat voorschriften voor de epidemiologische surveillance en controle van ernstige grensoverschrijdende bedreigingen van de gezondheid. Het stelt ook een systeem in voor vroegtijdige waarschuwing en bestrijding, het Early Warning and Response System, dat moet zorgen voor permanente communicatie tussen de Commissie en de nationale autoriteiten.

Technische en met name medische expertise is belangrijker dan ooit voor het nemen van de juiste beslissingen. Op EU-niveau bestaan daarvoor verschillende netwerken. Krachtens artikel 17 Besluit $1082 / 2013 / \mathrm{EU}$ is een expertgroep gecreëerd met vertegenwoordigers van de lidstaten. Tijdens de coronacrisis komt dit Gezondheidsbeveiligingscomité regelmatig bijeen. ${ }^{12}$ Voor 'epidemiologische surveillance' voorziet artikel 6 Besluit 1082/2013/EU in een afzonderlijke netwerk. In dit verband speelt ook het Europees Centrum voor ziektepreventie en -bestrijding (ECDC) een belangrijke rol als ondersteunend agentschap belast met het verzamelen van expertise en het ontwikkelen van programma's ter bestrijding van infectieziektes. ${ }^{13}$ De Europese Commissie heeft bovendien een Europees team van coronavirusdeskundigen opgericht dat richtsnoeren opstelt voor maatregelen om het besmettingsrisico te beheersen. Zo heeft de Commissie op basis van wetenschappelijk advies van het ECDC en van het adviespanel op 19 maart gemeenschappelijke gezondheidsmaatregelen aanbevolen, zoals afstand houden en het opstellen van teststrategieën. ${ }^{14}$

Het covid-19-virus raakt ook andere beleidsterreinen van de Unie. Het 'integratiebeginsel' van artikel 9 VWEU verplicht de EU bij al haar beleid en optreden rekening te houden met een hoog niveau van bescherming van de menselijke gezondheid. Daardoor komen de volksgezondheidsaspecten ook aan bod bij acties betreffende civiele bescherming, onderzoek en ontwik-

11. Besluit Nr. 1082/2013/EU van het Europees Parlement en de Raad van 22 oktober 2013 over ernstige grensoverschrijdende bedreigingen van de gezondheid en houdende intrekking van Beschikking nr. 2119/98/EG.

12. De verslagen van deze bijeenkomsten zijn te raadplegen onder https:// ec.europa.eu/health/preparedness_response/crisis_management_nl.

13. Zie www.ecdc.europa.eu/en voor dagelijkse updates.

14. Zie voor een overzicht van de adviezen https://ec.europa.eu/info/livework-travel-eu/health/coronavirus-response/publichealth_nl\#documents. 
keling, ${ }^{15}$ de interne markt, ${ }^{16}$ het mededingingsbeleid, het financiële en monetaire beleid en het externe beleid. Zoals hieronder zal blijken overlappen in de praktijk de bevoegdheden en initiatieven elkaar. Dat geldt vooral voor de financiële instrumenten om het covid-19-virus te bestrijden en de capaciteit van de volksgezondheid te vergroten. Deze zijn met name gebaseerd op de rechtsbases in het VWEU betreffende de volksgezondheid, de civiele bescherming en onderzoek. ${ }^{17}$ In dit verband moet ook melding worden gemaakt van de substantiële budgetten die worden vrijgemaakt om derde landen in de coronacrisis bij te staan en die (deels) gebaseerd zijn op de verdragsbepalingen betreffende de samenwerking met derde landen. ${ }^{18}$

\section{Aankoop van medisch materiaal}

In noodsituaties zoals bij de covid-19-pandemie ondervinden de aanbestedende diensten van de lidstaten aanzienlijke juridische en praktische moeilijkheden bij de aankoop van benodigdheden of diensten. Artikel 5 Besluit 1082/2013/EU biedt de rechtsbasis voor een gezamenlijke aanbestedingsprocedure voor de inkoop van geneesmiddelen en andere 'medische tegenmaatregelen' door de EU-instellingen en de lidstaten die dat wensen. De aanbestedingsprocedure mag geen afbreuk doen aan de interne markt, geen discriminatie of beperking van de handel inhouden of de mededinging verstoren. ${ }^{19}$

Tot dusverre zijn tijdens de coronacrisis vier procedures gestart voor de gezamenlijke aankoop van medische uitrustingen en persoonlijke beschermingsmiddelen (handschoenen, maskers, testkits, enz.) met als doel ervoor te zorgen dat de (25) deelnemende EU-landen op betere voorwaarden en tegen lagere prijzen kunnen beschikken over de noodzakelijke bevoorrading. ${ }^{20} \mathrm{Er}$ is kritiek geweest op de aanpak (te laat om de nood in landen als Italië en Spanje te verlichten, onduidelijke voorwaarden) en de levering verloopt niet altijd vlekkeloos (levering van ondeugdelijke producten ${ }^{21}$ ) maar de eerste zendingen aan zeventien landen zijn aangekomen.

15. Onderzoeksbudgetten voor het bestrijden van het coronavirus stelt de EU beschikbaar in het kader van de Europese onderzoeksruimte (art. 179 VWEU).

16. Art. 114 lid 3 VWEU verplicht de EU-instellingen bij interne marktmaatregelen uit te gaan van een hoog niveau van bescherming van de volksgezondheid.

17. Het betreft met name het European Stability Mechanism Pandemic Crisis Support for Member States en middelen die direct afkomstig zijn van de EU begroting zoals voor Horizon-onderzoek. Zo stelt het EU-initiatief 'Solidariteit voor gezondheid' 3 miljard euro steun beschikbaar voor de gezondheidsstelsels van de lidstaten.

18. De Commissie stelt in het herstelplan voor om de budgetten voor extern optreden, waaronder het Neighbourhood, Development and International Cooperation Instrument, met 16.5 miljard euro te verhogen.

19. De financiering van deze corona-aanbestedingen (en van andere uitgaven) is gereguleerd in Verordening (EU) 2020/521 van de Raad tot activering van noodhulp uit hoofde van Verordening (EU) 2016/369 (zie ook hierna). De verordening bevat gedetailleerde voorschriften voor de wijze waarop gezamenlijke aanbestedingen met de lidstaten georganiseerd kunnen worden.

20. https://ec.europa.eu/commission/presscorner/detail/nl/ip_20_523.

21. Waaronder in Nederland. Zie Agence Europe, 15 mei. De Commissie garandeert de levering maar is van mening dat de finale kwaliteitscontrole onder de verantwoordelijkheid van de lidstaten valt.
De Commissie heeft ook richtsnoeren vastgesteld voor een flexibele toepassing van het EU-rechtelijke kader voor nationale overheidsopdrachten bij de aankoop van goederen, diensten en werken die verband houden met de coronacrisis, waaronder ziekenhuis- en IT-infrastructuur. De richtsnoeren zijn gebaseerd op de flexibiliteit in de huidige EU-aanbestedingswetgeving, zoals verduidelijkt door het Hof van Justitie. ${ }^{22}$ Het betreft de mogelijkheden om de openbare of niet-openbare procedures te versnellen door de termijnen aanzienlijk te verkorten, dan wel - in uiterst spoedeisende gevallen gebruik te maken van een procedure van gunning door onderhandeling zonder bekendmaking.

\section{Noodhulp en beschikbaarheid van essentiële covid-19-producten}

Voor acuut optreden in tijden van pandemieën zijn ook de EU-bevoegdheden op het terrein van de civiele bescherming (art. 196 VWEU) van belang. Daarvoor bestaat het interinstitutionele Coördinatiecentrum voor respons in noodsituaties (ERCC) dat steun biedt in het kader van het RescEU-programma, het EU-financieringsmechanisme voor 'civiele rampen'. 23

Verordening (EU) 2020/521 van de Raad van 14 april 2020 activeert de noodhulp uit hoofde van Verordening (EU) 2016/369 en breidt de werking ervan uit om rekening te houden met de specifieke omstandigheden van covid-19. ${ }^{24}$ De verordening vormt de basis van het specifieke covid-19-instrument voor noodhulp (Emergency Support Instrument, ESI) met een EU-budget van 2,7 miljard euro.

Concreet gaat het om een breed pallet aan acties zoals de aanschaf van een voorraad essentiële producten (beademingstoestellen, mondkapjes enzovoort); het omschakelen van productiecapaciteit voor noodzakelijke medische producten; activiteiten ter ondersteuning van het beheer, toepassen en ontwikkelen van medische tests; het coördineren binnen de EU van het vervoer van medische uitrustingen en patiënten naar buurlanden; ${ }^{25}$

22. Zie Mededeling van de Commissie - Richtsnoeren van de Europese Commissie betreffende het gebruik van het kader voor overheidsopdrachten in de door de Covid-19-crisis veroorzaakte noodsituatie, PbEU 2020, C 108/1.

23. Besluit nr. 1313/2013/EU van het Europees Parlement en de Raad van 17 december 2013 betreffende een Uniemechanisme voor civiele bescherming.

24. Verordening (EU) $2020 / 521$ tot activering van noodhulp uit hoofde van Verordening (EU) $2016 / 369$, en tot wijziging van de bepalingen ervan rekening houdend met de uitbraak van Covid-19, PbEU 2020, L 117/3. Verordening 2020/521/EU is gebaseerd op art. 122 VWEU (in het hoofdstuk economisch beleid, zie ook hieronder) volgens welke de Raad, op voorstel van de Commissie 'in een geest van solidariteit tussen de lidstaten bij besluit de voor de economische situatie passende maatregelen vaststellen (...)'. Art. 3 van de verordening verklaart dat de uit hoofde van deze verordening verstrekte noodhulp toegekend en uitgevoerd moet worden 'met inachtneming van de fundamentele humanitaire beginselen van menselijkheid, neutraliteit, onpartijdigheid en onafhankelijkheid'.

25. Zie ook: Mededeling van de Commissie Richtsnoeren voor EU-noodhulp voor grensoverschrijdende samenwerking in de gezondheidszorg met betrekking tot de covid-19-crisis, PbEU 2020, C 111I. De richtsnoeren voorzien onder meer in regelingen voor grensoverschrijdende patiëntenmobiliteit en voor de terugbetaling van de kosten van behandelingen in andere landen. 
het ondersteunen van medische teams waaronder in vluchtelingenkampen, en het repatriëren van meer dan 550.000 EU-burgers. ${ }^{26}$

De Commissie stelde op 8 april richtsnoeren vast voor het garanderen van de aanvoer van geneesmiddelen. De lidstaten wordt aanbevolen tijdelijk flexibel om te gaan met de toepassing van de bestaande EU-regelgeving voor vergunningen, bijvoorbeeld door het invoeren van vereenvoudigde controleprocedures en het toestaan van een verlenging van de uiterste houdbaarheidsdatum. ${ }^{27}$

Onderzoek ter bestrijding van covid-19

In aanvulling op de specifieke stimuleringsmaatregelen voor onderzoek uit hoofde van artikel 168 VWEU zijn er ook ruimte onderzoeksbudgetten vrijgemaakt in het kader van de Europese onderzoeksruimte ex artikel 179 VWEU. Belangrijk is het EU-Horizon 2020 onderzoeks- en innovatieprogramma waarvoor al sinds januari 2020 substantiële budgetten beschikbaar worden gesteld voor de ontwikkeling van middelen tegen het covid-19virus (diagnose, behandeling, vaccins). ${ }^{28}$

De EU is bovendien actief op internationaal terrein. Op uitnodiging van de WHO en andere gezondheidsinstanties organiseerde het op 4 mei met mondiale partners (niet de regering van de VS) een breed opgezette donorconferentie waarbij ondertussen een bedrag van 9,8 miljard euro is toegezegd, inclusief 1,4 miljard euro van de Commissie (met middelen van Horizon 2020, rescEU, het noodhulpinstrument ESI en ook budgetten voor externe hulp). De wereldwijde coronarespons omvat publieke en private partnerschappen voor testen; behandelingen en preventie, alsmede versterking van de gezondheidszorgstelsels. De Europese Commissie coördineert het programma. ${ }^{29}$

Naast deze financiële solidariteitsacties doet zich de vraag voor naar de beschikbaarheid voor EU-burgers van het verlossende vaccin wanneer dat wordt ontwikkeld, geproduceerd en op de markt gebracht. Een EUstrategie voor corona-19-vaccins is angekondigd voor de week van 15 juni. De verwachting is dat hierbij wordt ingegaan op het waarborgen van de productie en levering van het vaccins in de EU (via Advance Purchase Agreements tussen de Commissie en de geneesmiddelenindustrie) en gelijke toegang voor iedereen. De rechtsbasis hiervoor is de ESI-verordening. Samen met het Europees geneesmiddelbureau (EMA) zal de Commissie

26. Zie de bijlage van Verordening (EU) 2020/521 voor een (niet-uitputtend) overzicht van het brede scala aan acties die door het instrument voor noodhulp worden gefinancierd.

27. Richtsnoeren inzake de optimale en rationele aanvoer van geneesmiddelen om tekorten tijdens de uitbraak van COVID-19 te voorkomen, PbEU 2020, C 1061.

28. Tot half mei werden voor ruim 400 miljoen euro 18 onderzoeksprojecten en 151 teams in heel Europa gefinancierd. Op 13 mei werd het bedrag voor urgent covid-19-onderzoek met ruim 120 miljoen euro verhoogd. Zie https://ec.europa.eu/commission/presscorner/detail/nl/ IP_20_887. Overigens stelde de EU al in 2012 budget beschikbaar voor het ontwikkelen van coronavaccins (sars en mers) maar de belangstelling van de industrie was - toen nog - gering.

29. Zie voor details de website https://global-response.europa.eu/index_nl en het persbericht https://ec.europa.eu/commission/presscorner/detail/ nl/ip_20_797. zich bovendien inspannen om de toelating van succesvolle vaccins volgens de EU-geneesmiddelenwetgeving met verkorte procedures zo soepel mogelijk te laten verlopen. ${ }^{30}$ Verder is onder meer van belang wie de intellectuele-eigendomsrechten en met name de octrooirechten op de (cocktail van) medicijnen zal bezitten. Voor de goedkeuring van nationale staatssteun aan onderzoeksprojecten in het kader van covid-19 en andere virussen vereist de Commissie dat de begunstigde van de steun zich ertoe verbindt om op niet-discriminerende marktvoorwaarden niet-exclusieve licenties te verlenen aan derden binnen de Europese Economische Ruimte (EER). ${ }^{31}$

\section{De 'corona-app' en de bescherming van persoonsgegevens}

Iedereen kent inmiddels het belang van 'test and trace' voor het beteugelen van het covid-19-virus. Een aantal lidstaten, waaronder Nederland, bestudeert het gebruik van een smartphone-app die moet helpen bij het waarschuwen van burgers die in contact zijn geweest met besmette personen. Sommige experts betwijfelen de technische haalbaarheid en de toegevoegde waarde van deze traceerapps. Het is echter onbetwist dat het succes van deze vrijwillige apps in sterke mate zal afhangen van het vertrouwen dat de burgers stellen in de wijze waarop met hun fundamentele grondrechten wordt omgegaan.

Een aanbeveling van de Commissie van 8 april moet bijdragen aan een succesvolle gecoördineerde aanpak op Unie-niveau. ${ }^{32}$ Praktisch betreft het de ontwikkeling van technische aspecten van de apps (inclusief interoperabiliteit en de grensoverschrijdende gevolgen daarvan) en het opzetten van een gemeenschappelijke regeling voor geanonimiseerde en geaggregeerde gegevens. Een week later al, op 17 april, heeft dat geleid tot de publicatie van een toolbox voor de lidstaten. ${ }^{33}$ De Europese

30. Zie voor een overzicht van de EU-wetgeving betreffende geneesmiddelen voor de mens en de gecentraliseerde goedkeuringsprocedure www.ema.europa.eu/en/human-medicines-regulatory-information.

Voor covid-19-geneesmiddelen heeft EMA een speciale taskforce in het leven geroepen, zie www.ema.europa.eu/en/news/covid-19-how-emafast-tracks-development-support-approval-medicines-vaccines.

31. Zie de Wijziging van de tijdelijke kaderregeling inzake staatssteun ter ondersteuning van de economie vanwege de huidige covid-19-uitbraak (2020/C 112 I/01), punt 18.

32. Aanbeveling (EU) $2020 / 518$ van de Commissie van 8 april 2020 over een gemeenschappelijke toolbox voor het gebruik van technologie en gegevens om de Covid-19-crisis te bestrijden en te boven te komen, met name wat mobiele applicaties en het gebruik van geanonimiseerde mobiliteitsgegevens betreft, PbEU 2020, L 114/7.

33. Zie voor de tekst https://ec.europa.eu/health/ehealth/covid-19_en. Bij de ontwikkeling van de toolbox is onder meer gebruikgemaakt van het 'e-gezondheidsnetwerk' dat is ingesteld krachtens art. 14 Patiëntenrichtlijn 2011/24/EU. Ook het Europees Comité voor gegevensbescherming (EDPB) en de Europese Toezichthouder voor gegevensbescherming zijn nauw betrokken bij de ontwikkeling van de toolbox. Het EDPB heeft op 21 april Richtsnoeren 4/2020 vastgesteld voor het gebruik van locatiegegevens en instrumenten voor contacttracering in het kader van de uitbraak van COVID-19. Zie ook de Richtsnoeren 3/2020 inzake de verwerking van gezondheidsgegevens voor wetenschappelijk onderzoek in het kader van de covid-19-uitbraak. Het betreft hierbij verduidelijkingen van het gebruik van gezondheidsgegevens voor onderzoeksdoeleinden als bedoeld in art. 4 lid 15 AVG. Zie https://edpb.europa.eu/sites/edpb/files/files/file1/

edpb_guidelines_202003_healthdatascientificresearchcovid19_nl.pdf. 
Commissie heeft tegelijkertijd ook richtsnoeren uitgevaardigd voor de vereisten waaraan corona-apps moeten voldoen met het oog op de naleving van de Algemene verordening gegevensbescherming (AVG) ${ }^{34}$ en de Eprivacyrichtlijn. ${ }^{35}$ Daarbij gaat het in het bijzonder om artikel 5 (algemene beginselen van gegevensverwerking); artikel 6 (gronden voor de rechtmatigheid van de gegevensverwerking) en artikel 9 lid 2 sub 1 AVG (verwerking van gegevens om redenen van volksgezondheid) alsmede artikel 5 E-privacyrichtlijn (vertrouwelijk karakter van communicatie).

Gezien de gevoeligheden is de Commissie van oordeel dat de nationale gezondheidsinstanties 'verwerkingsverantwoordelijke' moeten zijn voor de verwerking van de gegevens, ${ }^{36}$ met een degelijke rechtsgrondslag waarbij de precieze doeleinden van de verwerking duidelijk worden uiteengezet. Essentieel is verder dat de gebruiker toestemming geeft voor het verwerken van de informatie voor ieder van de verschillende appfunctionaliteiten (zoals informatie, symptoomcontrole, contacttracering en waarschuwingen). De gebruiker moet daarover ook voldoende worden ingelicht door de betrokken gezondheidsinstanties. ${ }^{37}$ De Commissie brengt bovendien het beginsel van gegevensminimalisatie in herinnering op grond waarvan alleen persoonsgegevens mogen worden verwerkt die geschikt en relevant zijn. Verder moet onder meer voldaan worden aan het beginsel van de beperking van de opslag dat vereist dat persoonsgegevens niet langer worden bewaard dan nodig is, en moet de beveiliging van de gegevens zijn gewaarborgd.

In wezen geeft de Commissie dus aanwijzingen over de wijze waarop de huidige EU-wetgeving in de context van covid-19 moet worden uitgelegd. In de praktijk blijkt het niet eenvoudig de traceerapps en hun toepassing met deze reguliere beginselen in overeenstemming te brengen. Het kan bijvoorbeeld onduidelijk zijn wie verantwoordelijk is voor de verwerking van de gegevens. Ook is onzeker of voor de privacy minder ingrijpende alternatieven niet even effectief kunnen zijn om het virus te bestrijden. ${ }^{38}$

34. Verordening (EU) 2016/679 van het Europees Parlement en de Raad van 27 april 2016 betreffende de bescherming van natuurlijke personen in verband met de verwerking van persoonsgegevens en betreffende het vrije verkeer van die gegevens en tot intrekking van Richtlijn 95/46/EG (Algemene verordening gegevensbescherming), PbEU 2016, L 119/1.

35. Richtlijn 2002/58/EG van het Europees Parlement en de Raad van 12 juli 2002 betreffende de verwerking van persoonsgegevens en de bescherming van de persoonlijke levenssfeer in de sector elektronische communicatie (Richtlijn betreffende privacy en elektronische communicatie), PbEG 2002, L 201/37

36. Zie ook overweging 45 AVG

37. In overeenstemming met de transparantiebepalingen van art. 12 en 13 AVG.

38. Zie de kritiek van de Autoriteit Persoonsgegevens op de oorspronkelijke opzet van de zeven app-voorstellen die het ministerie van VWS in april selecteerde: https://autoriteitpersoonsgegevens.nl/nl/nieuws/apprivacy-corona-apps-niet-aangetoond. In Noorwegen is de ontwikkeling van de corona-app om redenen van privacy stopgezet.
Desinformatie en het aanbod van covid-19-

namaakproducten

Vanaf het prille begin spelen malafide ondernemingen en individuen in op de angsten bij burgers door valste informatie te verspreiden over middelen die een covid-19-infectie zouden kunnen voorkomen of genezen. Er is ook bewijs van het speciale anti-desinformatieteam van de EU dat onjuiste beweringen over de coronacrisis afkomstig zijn uit landen als China en Rusland en een specifieke politieke bedoeling hebben. ${ }^{39} \mathrm{Val}-$ se informatie is niet noodzakelijkerwijs onwettig maar zeker ongewenst en een serieuze bedreiging voor een pluralistisch democratisch debat. De Commissie heeft samen met Hoge Vertegenwoordiger Borrell op 10 juni een mededeling uitgevaardigd om desinformatie over covid-19 te bestrijden. Centraal daarbij staat transparantie en samenwerking met online platforms om deze 'wereldwijde infodemie' te bestrijden. ${ }^{40}$

Het aanbieden van illegale producten en misleidende reclame is ontoelaatbaar. $\mathrm{Bij}$ e-commerce platforms is een groeiend aanbod ontstaan van fake covid-19-producten zoals beschermingsmaskers, mondkapjes en desinfecterende zeep. Deze activiteiten kunnen illegaal zijn uit hoofde van de EU-productenwetgeving (zie hieronder); de Richtlijn oneerlijke handelspraktijken en/of op grond van de Richtlijn betreffende de handhaving van intellectueel-eigendomsrecht. ${ }^{41}$

De samenwerking is daarom geenszins vrijblijvend. Online platforms die niet prompt optreden tegen 'onwettige activiteiten en informatie' lopen het risico hun aansprakelijkheidsexceptie op grond van artikel 14 Richtlijn elektronische handel te verliezen. ${ }^{42}$ Daardoor kunnen zij aansprakelijkheid worden gehouden voor de schade die de illegale content veroorzaakt.

Op 20 maart hebben de nationale autoriteiten voor consumentenbescherming van de EU-landen die samenwerken in het kader van Verordening (EU) 2017/2394, ${ }^{43}$ (SCB-netwerk) met steun van de Commissie een gemeenschappelijk standpunt uitgebracht over de meest voorkomende vormen van oplichting en oneerlijke praktijken rondom het coronavirus. De natio-

39. https://euvsdisinfo.eu/eeas-special-report-disinformation-on-thecoronavirus-short-assessment-of-the-information-environment/.

40. Gezamenlijke Mededeling - Desinformatie in verband met covid-19aanpakken: feiten onderscheiden van fictie, JOIN(2020) 8 final. Zie voor meer details de specifieke website https://ec.europa.eu/info/live-worktravel-eu/health/coronavirus-response/fighting-disinformation_nl.

41. Richtlijn 2005/29/EG van het Europees Parlement en de Raad van 11 mei 2005 betreffende oneerlijke handelspraktijken van ondernemingen jegens consumenten op de interne markt (Richtlijn oneerlijke handelspraktijken), PbEU 2005, L 149/22-39; Richtlijn 2004/48/EG van het Europees Parlement en de Raad van 29 april 2004 betreffende de handhaving van intellectuele-eigendomsrechten, PbEU 2004, L 195/16-25.

42. Richtlijn 2000/31/EG van het Europees Parlement en de Raad van 8 juni 2000 betreffende bepaalde juridische aspecten van de diensten van de informatiemaatschappij, met name de elektronische handel, in de interne markt (Richtlijn inzake elektronische handel), PbEG 2000, L 178/1-16.

43. Verordening (EU) $2017 / 2394$ van het Europees Parlement en de Raad van 12 december 2017 betreffende samenwerking tussen de nationale autoriteiten die verantwoordelijk zijn voor handhaving van de wetgeving inzake consumentenbescherming en tot intrekking van Verordening (EG) nr. 2006/2004, PbEU 2017, L 345/1-26. 
nale autoriteiten maakten daarbij gebruik van hun nieuwe bevoegdheden om per 1 januari 2020 strenger op te treden tegen grensoverschrijdende inbreuken in de online wereld. ${ }^{44}$ Vervolgens heeft de Europees Commissaris voor Justitie en Consumenten een aantal e-commerce platforms, sociale media en zoekmachines schriftelijk gevraagd om tegen fraudeurs op te treden. De maatregelen die platforms zoals Google, Amazon, Facebook en Alibaba hebben genomen worden op de website van de Commissie gepubliceerd. ${ }^{45}$ Op 30 april heeft het SCB-netwerk een zogeheten smeep gehouden, een gezamenlijke actie om illegale coronagerelateerde producten offline te halen. ${ }^{46}$

Ook Europol en OLAF (European Anti-Fraud Office) houden gerichte acties tegen criminele coronaoplichters. Daarbij wordt nauw samengewerkt met politie en douaneautoriteiten. ${ }^{47}$

\section{De interne markt}

\section{Grenscontroles voor het personenverkeer ${ }^{48}$}

Sinds het virus oversloeg naar Italië hebben de lidstaten een aantal drastische maatregelen genomen om de verspreiding van het virus te beperken. Alle EU-landen hebben samenscholingen verboden, regels voor sociale afstand vastgesteld, scholen en fabrieken (geheel of gedeeltelijk) gesloten en reisbeperkingen opgelegd. In meer dan de helft van de EU-landen werd de noodtoestand uitgeroepen. ${ }^{49}$ Een ongekende beperking op de mobiliteitsvrijheden die Europa sinds de Tweede Wereldoorlog niet heeft gekend.

Concreet heeft dit met name gevolgen voor het Schengengebied. Waar aanvankelijk de Schengenlanden haast zonder overleg overgingen tot het invoeren van grenscontroles, vindt ondertussen meer coördinatie plaats om de controles weer op te heffen. ${ }^{50}$

Op grond van artikel 7 en 8 Schengengrenscode ${ }^{51}$ is het mogelijk de toegang te weigeren aan niet-ingezeten

44. Zie hoofdstuk IV van Verordening (EU) 2017/2394.

45. https://ec.europa.eu/info/live-work-travel-eu/consumers/enforcementconsumer-protection/scams-related-covid-19_nl\#advice-to-consumersand-traders.

46. Zie voor de resultaten https://ec.europa.eu/commission/presscorner/ detail/en/IP_20_938.

47. Zie voor een goed overzicht www.europol.europa.eu/publicationsdocuments/viral-marketing-counterfeits-substandard-goods-andintellectual-property-crime-in-covid-19-pandemic Zie voor de acties van OLAF https://ec.europa.eu/anti-fraud/media-corner/news/ 13-05-2020/inquiry-fake-covid-19-products-progresses_en.

48. Zie voor een uitgebreidere analyse het artikel van $\mathrm{H}$. van Eijken en J.J. Rijpma elders in deze aflevering van NtEr: 'Social distancing voor lidstaten: grenscontroles en vrij verkeer in tijden van covid-19'.

49. Gezamenlijk Stappenplan, p. 2.

50. De Commissie heeft een coördinatiegroep, de 'Covid-19/corona-informatiegroep - Grenskwesties', opgericht, die wekelijks vergadert met de EU-landen, geassocieerde Schengenlanden, het secretariaat-generaal van de Raad en het Europees Grens- en kustwachtagentschap. Er is een website met een geactualiseerd overzicht van de nationale grensmaatregelen per land: https://ec.europa.eu/transport/coronavirusresponse_nl.

51. Verordening (EU) $2016 / 399$ van het Europees Parlement en de Raad van 9 maart 2016 betreffende een Uniecode voor de overschrijding van onderdanen van derde landen, wanneer zij relevante symptomen vertonen of sterk aan besmettingsgevaar zijn blootgesteld, en worden beschouwd als gevaar voor de volksgezondheid. ${ }^{52}$ De Commissie heeft de lidstaten op 16 maart aanbevolen een inreisverbod in te stellen voor niet-essentiële reizen vanuit landen buiten de EU. ${ }^{53}$ De EU-leiders zijn hiermee akkoord gegaan en alle EUlanden (behalve Ierland) en alle geassocieerde Schengenlanden (IJsland, Liechtenstein, Noorwegen en Zwitserland) passen deze reisbeperking toe. De aanbeveling wordt regelmatig met een maand verlengd en de tijdelijke beperking geldt thans tot 15 juni $2020 .^{54}$

De Schengengrenscode staat lidstaten ook toe om tijdelijk grenscontroles voor landen binnen de $E U$ in te voeren, mits gerechtvaardigd om redenen van algemeen belang of veiligheid. ${ }^{55} \mathrm{Op} 16$ maart heeft de Commissie richtsnoeren vastgesteld over de condities waaronder deze controles in uitzonderlijke situaties weer mogen worden ingevoerd als een reactie op risico's van besmettelijke ziekten. ${ }^{56}$

In hoeverre reisbeperkingen binnen het Schengengebied kunnen worden opgeheven, hangt in grote mate af van de ontwikkeling van de pandemie en nationale epidemiologische omstandigheden, waarbij in toenemende mate ook sociale en economische overwegingen zoals herstel van het toerisme worden betrokken. De Schengenlanden hebben verschillende suggesties gedaan, waaronder bilaterale overeenkomsten met minder getroffen landen (Oostenrijk); de afgifte van gezondheidsverklaringen voor reizigers (Griekenland) en het creëren van 'toeristische corridors' tussen EU-lidstaten (Kroatië).

Het stappenplan van 15 april roept op tot een gefaseerde aanpak. Op 13 mei heeft de Commissie criteria en beginselen bekendgemaakt voor een geleidelijke en gecoördineerde terugkeer van het vrije personenverkeer in drie fasen. ${ }^{57}$ De Commissie eist dat wanneer een lidstaat besluit reizen naar zijn grondgebied of naar specifieke regio's en gebieden binnen zijn grondgebied toe te staan, of juist nog te beperken, dat op niet-discriminerende en objectieve wijze moet plaatsvinden. Dat kan lastig zijn waar een land grensmaatregelen voor het gehele grondgebied neemt, maar de epidemiologische situatie per regio sterk verschilt.

de grenzen door personen (Schengengrenscode) (codificatie), PbEU 2016, L 77/1-52.

52. Zie met name art. 2 punt 21; art. 6 lid 1 onder e en art. 14 Schengengrenscode.

53. Zie met name: Covid-19: Leidraad voor de uitvoering van de tijdelijke beperking van niet-essentiële reizen naar de EU, het faciliteren van doorreisregelingen voor de repatriëring van EU-burgers, en de gevolgen voor het visumbeleid, PbEU 2020, C 102 I/02

54. https://ec.europa.eu/commission/presscorner/detail/nl/ip_20_823.

55. Zie met name art. 25 Schengengrenscode.

56. Covid-19-Richtsnoeren voor grensbeheermaatregelen tot bescherming van de gezondheid en tot waarborging van de beschikbaarheid van goederen en essentiële diensten, PbEU 2020, C 861.

57. Covid-19 - Naar een gefaseerde en gecoördineerde aanpak van het herstel van het vrije verkeer en de opheffing van de binnengrenscontroles, PbEU 2020, C 169/30 
Grenscontroles voor goederen en vervoersdiensten In deze crisis is binnen de EU ook een onbelemmerd goederenverkeer cruciaal, vanwege mogelijke nationale tekorten en uiteraard ook voor de goede werking van de interne markt. Recentelijk onderstreepte de Brexitdiscussie al de grote economische betekenis van de sterk geïntegreerde Europese toeleveringsketens die afhankelijk zijn van geavanceerde netwerken voor het vervoer over de weg, over het water en door de lucht. Doordat lidstaten tijdelijk opnieuw personencontroles aan de binnengrenzen invoerden, verdween ook de vanzelfsprekendheid van ononderbroken vervoersdiensten. De nationale grensmaatregelen makten oponthoud voor het goederenverkeer onvermijdelijk.

Sinds 16 maart heeft de Commissie voor het garanderen van continue vervoersdiensten aan de grenzen diverse richtsnoeren uitgevaardigd. Deels komen die overeen met de aanwijzingen voor het personenverkeer, omdat ze dezelfde bepalingen van de Schengengrenscontrole betreffen. Zo roept de Commissie de lidstaten op maatregelen aan de grenzen in EU-verband te coördineren. Evenals bij het personenverkeer moeten de uitzonderlijke maatregelen ook voor het goederenverkeer noodzakelijk en proportioneel zijn. ${ }^{58}$

De lidstaten werd gevraagd onmiddellijk alle essentiële binnengrensovergangen op het trans-Europees vervoersnetwerk (TEN-T) als speciale rijstroken (green lanes) aan te wijzen. De passage van de grens op een green lane mag niet meer dan 15 minuten duren, alle controles en medische screenings inbegrepen. Dit is een uitzonderlijke situatie waarin de Commissie de lidstaten oproept zo flexibel mogelijk te zijn. ${ }^{59}$

De officiële controles en andere formaliteiten door nationale autoriteiten op grond van de EU-wetgeving voor levensmiddelen, dierenvoeding, planten en gewasbeschermingsmiddelen zijn tijdens de crisis onder druk komen te staan wegens een gebrek aan personeel. De Commissie heeft de regels tijdelijk - voorlopig tot 1 augustus 2020 - versoepeld. Daardoor kunnen lidstaten controles laten uitvoeren door tijdelijk gemachtigde personen en laboratoria en mogen bedrijven bij wijze van uitzondering kopieën van originele stukken elektronisch overleggen. ${ }^{60}$

Toerisme, tegoedbonnen en de luchtvaart Om het toerismeseizoen van zomer 2020 nog enigszins te redden heeft de Commissie op 13 mei een reeks richtsnoeren gegeven voor lidstaten, reizigers en onderne-

58. Covid-19-Richtsnoeren voor grensbeheermaatregelen tot bescherming van de gezondheid en tot waarborging van de beschikbaarheid van goederen en essentiële diensten, PbEU 2020, C 861 .

59. Mededeling van de Commissie over de toepassing van 'green lanes' in het kader van de richtsnoeren voor grensbeheermaatregelen om de gezondheid te beschermen en de beschikbaarheid van goederen en essentiële diensten te verzekeren, PbEU 2020, C 961.

60. Uitvoeringsverordening (EU) $2020 / 466$ van de Commissie van 30 maart 2020 betreffende tijdelijke maatregelen ter beperking van risico's voor de gezondheid van mensen, dieren en planten en voor het dierenwelzijn tijdens bepaalde ernstige storingen van de controlesystemen van de lidstaten als gevolg van de coronavirusziekte (Covid-19), PbEU 2020, L 94. mers. ${ }^{61}$ Naast aanbevelingen voor het geleidelijk openstellen van de binnengrenzen ziet het pakket ook op richtsnoeren om de risico's voor reizigers en toeristen tijdens het vervoer, in de horeca en in hotelaccommodaties via gezondheidsprotocollen tot een minimum te beperken. In de pers krijgen met name de aanwijzingen om de veiligheid van vliegpassagiers te garanderen veel aandacht. ${ }^{62}$ Een interactieve applicatie geeft geactualiseerde informatie om reizen en vakanties te plannen. ${ }^{63}$ Het pakket bevat verder economische steunmaatregelen voor de zwaar getroffen toeristische sector. ${ }^{64}$

Veel media-aandacht ook voor de aanbeveling van de Commissie betreffende de tegoedbonnen of vouchers. ${ }^{65}$ De verordeningen die per vervoerssector op uniforme wijze de passagiersrechten regelen, zijn daarvoor het belangrijkste rechtskader. ${ }^{66}$ In geval van annulering door de vervoerder hebben passagiers de keuze tussen een vergoeding en vervoer langs een andere route. Aangezien vervoer langs een andere route in tijden van crisis geen serieuze optie is, blijft de facto alleen de keuze tussen de verschillende vergoedingsmogelijkheden over. Reeds op 18 maart had de Commissie in 'interpretatierichtsnoeren' aangegeven hoe de EU-wetgeving voor passagiersrechten in de context van de corona-uitbraak moet worden toegepast. De Commissie herinnerde eraan dat passagiers de keuze hebben tussen terugbetaling in geld en vergoeding in de vorm van een voucher. Vergoeding door middel van een voucher is echter alleen toegestaan als de passagier daarmee instemt. ${ }^{67}$

Daarnaast bepaalt artikel 12 Richtlijn pakketreizen dat reizigers recht hebben op een volledige terugbetaling wanneer een pakketreis wordt geannuleerd wegens 'onvermijdbare en buitengewone omstandigheden'. Het is ook hier mogelijk dat organisatoren in deze coronaomstandigheden vouchers aanbieden aan hun reizigers. Dit ontneemt de reizigers echter niet het recht op terugbetaling. 68

61. Mededeling van de Commissie - Toerisme en vervoer in en na 2020, Brussel, $\operatorname{COM}(2020) 550$ final.

62. Zie naast de richtsnoeren van de Commissie ook de protocollen opgesteld door het Europees Agentschap voor de veiligheid van de luchtvaart (EASA) en de ECDC: www.easa.europa.eu/sites/default/files/dfu/ EASA-ECDC_COVID-19_Operational\%20guidelines\%20for $\% 20$ management $\% 20$ of\%20passengers_final.pdf.

63. https://reopen.europa.eu/nl/\#/en.

64. Zie voor een uitgebreid overzicht https://ec.europa.eu/info/live-worktravel-eu/health/coronavirus-response/travel-and-transportationduring-coronavirus-pandemic_nl.

65. Aanbeveling (EU) $2020 / 648$ van de Commissie van 13 mei 2020 inzake vouchers die aan passagiers en reizigers worden aangeboden als alternatief voor terugbetaling van geannuleerde pakketreizen en vervoersdiensten in het kader van de COVID-19-pandemie, PbEU 2020, L 151.

66. Verordeningen (EG) nr. 261/2004 (luchtreizigers), (EG) nr. 1371/2007 (treinreizigers), (EU) nr. 1177/2010 (passagiers die over zee of binnenwateren reizen) en (EU) nr. 181/2011 (autobus en touringcarpassagiers) van het Europees Parlement en de Raad.

67. Zie voor luchtreizigers bijvoorbeeld art. 5 en 8 Verordening (EG) nr. $261 / 2004$.

68. Richtlijn (EU) 2015/2302 van het Europees Parlement en de Raad van 25 november 2015 betreffende pakketreizen en gekoppelde reisarrangementen, houdende wijziging van Verordening (EG) nr. 2006/2004 en van Richtlijn 2011/83/EU van het Europees Parlement en de Raad, en intrekking van Richtlijn 90/314/EEG van de Raad, PbEU 2015, L 326/1-33. Zie ook de informele richtsnoeren over de toepassing van de 
In haar aanbeveling van 13 mei spoort de Commissie de vervoerders en reisorganisaties aan het systeem van tegoedbonnen voor passagiers en reizigers zo aantrekkelijk mogelijk te maken, om daarmee verzoeken tot terugbetaling (met alle gevolgen voor de liquiditeit van de vervoerders) te ontmoedigen. Zo wordt aanbevolen de vouchers te beschermen tegen insolventie van de uitgever (een taak ook voor de lidstaten en de garantiestelsels $\left.{ }^{69}\right)$. Ook zouden ze, bij niet-gebruik, ten laatste één jaar na afgifte moeten worden terugbetaald, en suggereert de Commissie de vouchers ook voor andere diensten dan vervoer te laten gebruiken. ${ }^{70}$

Een belangrijk punt, onderbelicht in de aanbevelingen en richtsnoeren van de Commissie, is de transparantie. ${ }^{71}$ Waar informatie over het gebruik van vouchers bij vervoerders ruimschoots aanwezig is, blijft voor veel reizigers onduidelijk hoe ze hun recht op vergoeding kunnen uitoefenen.

Verordening (EEG) nr. 95/93 stelt regels vast voor de toewijzing van zogeheten slots op EU-luchthavens. Artikel 10 bevat een use-it-or-lose-it-clausule. Ter benutting van de volledige capaciteit van vliegvelden moeten luchtvaartmaatschappijen minimaal 80 procent van de slots gebruiken die hun binnen een dienstregelingsperiode (zomer of winter) zijn toegewezen. Zo behouden ze hun grandfather-rights in het volgende jaar. Om de gevolgen van de sterke daling van het luchtverkeer op te vangen en milieuonvriendelijke ghost flights te voorkomen, zijn luchtvaartmaatschappijen tijdelijk van deze verplichting vrijgesteld. ${ }^{72}$

\section{Het vrij verkeer van goederen}

\section{De markttoegang van covid-19-producten}

De uitbraak van covid-19 heeft geleid tot een scherpe toename van de vraag naar persoonlijke beschermingsmiddelen, medische hulpmiddelen en andere covid-19gerelateerde producten. Daardoor zijn veel ondernemingen - binnen en buiten de gezondheidssector - begonnen met het produceren van maskers, ventilators en desinfecterende gels. De reconversie heeft ertoe geleid dat brouwerijen handgels maken, modehuizen zich toeleggen op gezichtsmaskers en fabrikanten van stofzuigers zich richten op ventilators. Er is ook een grote groep

Richtlijn pakketreizen die de Commissie op 19 maart op haar website heeft gepubliceerd: https://ec.europa.eu/info/sites/info/files/ coronavirus_info_ptd_19.3.2020.pdf, gepubliceerd op de website van de Commissie over de aanpak van covid-19: https://ec.europa.eu/info/ live-work-travel-eu/health/coronavirus-response/travel-andtransportation-duringcoronavirus-pandemic_nl.

69. De lidstaten kunnen bijvoorbeeld specifieke garantieregelingen voor vouchers opzetten, rechtstreeks gebaseerd op de staatssteun-ontheffingsgrond van art. 107 lid 3 onder b VWEU.

70. Vanwege de uitzonderlijke situatie is de ACM ook coulant bij een beoordeling van voucherregelingen, zie www.acm.nl/nl/publicaties/ acm-biedt-branches-houvast-bij-opstellen-voucherregeling.

71. Zie bijvoorbeeld voor luchtreizigers art. 14 lid 2 Verordening (EG) nr. $261 / 2004$

72. Verordening (EU) $2020 / 459$ van het Europees Parlement en de Raad van 30 maart 2020 tot wijziging van Verordening (EEG) nr. 95/93 van de Raad betreffende de toewijzing van slots op communautaire luchthavens, PbEU 2020, L 99/1. kleine ondernemingen die met 3D-printingtechnieken een bijdrage levert aan het oplossen van de schaarste.

Voor het commercialiseren van deze producten moeten alle bedrijven niettemin voldoen aan de vereisten van de EU-productnormen voor de CE-certificering en de markttoegang. De essentiële technische vereisten voor de producten zijn voorgeschreven in EU-richtlijnen en verordeningen. De details van deze vereisten worden ontwikkeld door de Europese normalisatie-instelling (CEN, CENELEC). Door middel van deze geharmoniseerde normen kunnen ondernemers bewijzen dat hun producten aan de vereiste relevante EU-wetgeving voldoen.

Hoewel de beginselen van deze productvoorschriften in grote mate met elkaar overeenkomen, ${ }^{73}$ zijn er ook duidelijke verschillen in de procedures voor certificering en markttoegang, afhankelijk van de complexiteit van het product en de risico's voor de volksgezondheid.

Zo zijn persoonlijke beschermingsmiddelen als medische gezichtsmaskers, chirurgische lakens, schorten en pakken geregeld in Verordening (EU) 2016/425. Op grond van deze verordening moeten bepaalde beschermingsmiddelen met een hoog risico (categorie III-producten) worden onderworpen aan een conformiteitsbeoordeling uitgevoerd door een onafhankelijke instantie. Voor medische hulpmiddelen zoals ventilators is thans Richtlijn 93/42/EEG van toepassing en is een conformiteitsbeoordeling door een erkend onafhankelijk orgaan niet verplicht. ${ }^{74}$ Desinfecterende handgels zijn biociden die vallen onder de reikwijdte van de Biocidenverordening 528/2012 (met vereiste van een toestemming voor markttoegang en gebruik $)^{75}$ waar handgels die alleen bedoeld zijn om te reinigen cosmetische goederen zijn waarop de Cosmeticaverordening $1223 / 2009^{76}$ van toepassing is (zonder vergunningsvereiste maar wel met een goedkeuringsvereiste voor werkzame stoffen).

Deze EU-wetgeving kent uitzonderingen van toestemmingsvereisten in geval van acute gevaren voor de volksgezondheid. Zo staat artikel 55 Biocidenverordening $528 / 2012$ de bevoegde autoriteiten toe om voor een periode van ten hoogste 180 dagen een biocide die niet aan de in de verordening vastgelegde voorwaarden

73. Zie hierover naar aanleiding van nieuwe 'horizontale' verordeningen op het gebied van geharmoniseerde en niet-geharmoniseerde productnormen T. Van Rijn, 'Nieuwe impulsen voor het vrije goederenverkeer', NtEr 2019/9-10, p. 279.

74. Wegens covid-19 hebben de Raad en het Europees Parlement besloten de toepassing van de nieuwe Verordening medische hulpmiddelen met één jaar uit te stellen, tot 21 mei 2022. Bedrijven kunnen er dus voor kiezen om een jaar later te voldoen aan de vereisten van de nieuwe verordening. Zie Verordening (EU) 2020/561 van het Europees Parlement en de Raad van 23 april 2020 tot wijziging van Verordening (EU) 2017/745 betreffende medische hulpmiddelen wat de datum van toepassing van een aantal bepalingen ervan betreft, PbEU 2020, L 130.

75. Verordening (EU) nr. 528/2012 van het Europees Parlement en de Raad van 22 mei 2012 betreffende het op de markt aanbieden en het gebruik van biociden, PbEU 2012, L 167. Zie voor de beginselen voor toelating art. 17-19

76. Verordening (EG) nr. 1223/2009 van het Europees Parlement en de Raad van 30 november 2009 betreffende cosmetische producten, PbEU 2009, L 342/59. Zie hoofdstuk II voor de vereisten en procedure inzake de goedkeuring van werkzame stoffen. 
voldoet, toch op de markt toe te laten 'indien die maatregel noodzakelijk is wegens een niet op andere wijze te bestrijden gevaar voor de volksgezondheid (...)'. De autoriteiten van andere lidstaten en de Commissie moeten wel worden ingelicht. Verschillende landen, waaronder Nederland, maken tijdens de coronacrisis gebruik van deze bevoegdheid. ${ }^{77}$

De Commissie heeft richtsnoeren uitgevaardigd om procedures bij toezichthouders te versoepelen zonder afbreuk te doen aan de essentiële veiligheidsnormen. Voor het verhogen van de productiecapaciteit deed de Commissie bijvoorbeeld reeds op 13 maart een aanbeveling waarbij de lidstaten en de markttoezichthouders worden aangespoord om prioriteit te geven aan het testen van covid-19-relateerde producten en daarbij ook uit te gaan van de WHO-aanbevelingen voor het beoordelen van producten die niet in overeenstemming met de geharmoniseerde normen zijn gefabriceerd. ${ }^{78}$ Voor een beperkte groep van medische hulpmiddelen heeft de Commissie herziene geharmoniseerde normen vastgesteld waardoor een snellere en goedkopere conformiteitsbeoordelingsprocedure mogelijk is. ${ }^{79}$

De Commissie biedt verder specifiek advies over de toepasselijke wetgeving om fabrikanten te helpen de productie op te voeren. Deze hebben betrekking op persoonlijke beschermingsmiddelen en 3D-printing. De 'richtsnoeren' bestaan met name uit vragen en antwoorden over de classificatie van de producten en de te volgen procedures voor markttoegang. ${ }^{80}$

Voor covid-19-tests is momenteel Richtlijn 98/79/EG betreffende medische hulpmiddelen voor in-vitrodiagnostiek van toepassing. ${ }^{81}$ De Commissie heeft op 15 april richtsnoeren gepubliceerd met een overzicht van het regelgevend kader, de doeleinden van de beschikbare testen en ook overwegingen met betrekking tot de

77. Tijdelijke vrijstelling op grond van artikel 46 , eerste lid van de Wet gewasbeschermingsmiddelen en biociden inzake desinfectiemiddelen in verband met de uitbraak covid-19 (Tijdelijke vrijstelling handdesinfectie covid-19 2020), zie https://wetten.overheid.nl/ BWBR0043280/2020-06-12.

78. Aanbeveling (EU) $2020 / 403$ van de Commissie van 13 maart 2020 betreffende conformiteitsbeoordelings- en markttoezichtsprocedures in het kader van de Covid-19-dreiging, PbEU 2020, L79I. Rectificatie in PbEU 2020, L 84.

79. https://ec.europa.eu/info/live-work-travel-eu/health/coronavirusresponse/public-health_nl.

80. Zie bijvoorbeeld 'Procedures voor conformiteitsbeoordeling van het 3Dprinten en 3D-gedrukte producten voor gebruik in een medische context in verband met covid-19', samen met de andere richtsnoeren te raadplegen onder https://ec.europa.eu/info/live-work-travel-eu/ health/coronavirus-response/public-health_nl. 3D-printers vallen met name onder de definitie van machines als vastgesteld in Richtlijn 2006/42/EG (de Machinerichtlijn). 3D-gedrukte producten kunnen worden gebruikt om medische hulpmiddelen te produceren die onder specifieke EU-productwetgeving vallen, zoals de Richtlijn medische hulpmiddelen (Richtlijn 93/42/EEG). De adviezen hebben geen betrekking op andere relevante juridische aspecten, zoals aansprakelijkheidsrisico's of inbreuken op intellectuele-eigendomsrechten.

81. De richtlijn wordt met ingang van 26 mei 2022 vervangen door Verordening (EU) 2017/746 betreffende medische hulpmiddelen voor invitrodiagnostiek. De verordening voorziet echter al in een overgangsperiode die begint op de datum van inwerkingtreding van de verordening (in mei 2017) en tijdens welke de conformiteit van medische hulpmiddelen voor in-vitrodiagnostiek zowel op grond van de verordening als op grond van de richtlijn mag worden beoordeeld. efficiëntie van de verschillende covid-19-testmethoden. Het wekt geen verbazing dat de Commissie de lidstaten aanspoort hun testcapaciteit uit te breiden. ${ }^{82}$

Ten slotte bereikten de Commissie en de Europese normalisatie-instellingen een akkoord om tijdens de covid-19-crisis alle relevante EU-geharmoniseerde normen voor de meest relevante producten bij wijze van uitzondering gratis en volledig beschikbaar te stellen voor belangstellende bedrijven. ${ }^{83}$

\section{Het vrije verkeer van schaarse goederen}

Naast het opvoeren van de productie is er nog een andere manier om de schaarste te bestrijden. In de beginfase van de coronacrisis stelden veel lidstaten beperkingen in om de uitvoer van essentiële goederen zoals medicijnen (inclusief tussenproducten of werkzame farmaceutische bestanddelen) tegen te gaan.

Op deze handelsbelemmeringen is artikel $35 \mathrm{VWEU}$ van toepassing. Deze bepaling verbiedt de lidstaten om kwantitatieve uitvoerrestricties en 'maatregelen van gelijke werking' in te voeren of te handhaven. ${ }^{84} \mathrm{De}$ belemmeringen kunnen op grond van artikel $36 \mathrm{VWEU}$ echter gerechtvaardigd zijn uit hoofde van het algemeen belang, waarbij de bescherming van de volksgezondheid de lidstaten een ruime marge geeft en ook het voorzorgsbeginsel een belangrijke rol speelt. ${ }^{85}$ Die marge is echter niet onbeperkt. De beperkingen moeten voldoen aan de vereisten van noodzakelijkheid en evenredigheid, en de bewijslast voor de rechtvaardigingsgrond ligt bij de lidstaten. ${ }^{86}$ Het ontstaan van een tekort aan geneesmiddelen of andere essentiële goederen in de strijd tegen corona kan binnen de marges vallen maar vereist niettemin een zorgvuldige afweging per geval.

In de coronatijd wordt veelvuldig gebruikgemaakt van de kennisgevingsprocedure van Richtlijn 2015/1535/ EG. ${ }^{87}$ Lidstaten notificeren de maatregelen in de ontwerpfase $^{88}$ waardoor een standstill periode van kracht

82. Mededeling van de Commissie - Richtsnoeren betreffende diagnostische in-vitrotests voor covid-19 en hun prestaties, PbEU 2020, C 1221 .

83. https://ec.europa.eu/growth/coronavirus-response\#protectiveproducts.

84. Het Hof van Justitie heeft in vaste rechtspraak bepaald dat art. 35 VWEU betrekking heeft op 'nationale maatregelen die een specifieke beperking van het uitgaande goederenverkeer tot doel of tot gevolg hebben en aldus tot een ongelijke behandeling van de binnenlandse handel en de uitvoerhandel van een lidstaat leiden, waardoor aan de nationale productie of de binnenlandse markt van de betrokken lidstaat ten koste van de productie of de handel van andere lidstaten een bijzonder voordeel wordt verzekerd.' Zie bijvoorbeeld HvJ 2 oktober 2003, zaak C-12/02, ECLI:EU:C:2003:538 (Grilli), punt 41.

85. Volgens het Hof van Justitie neemt van alle algemene belangen 'de gezondheid en het leven van personen de eerste plaats in', zie reeds HvJ 20 mei 1976, zaak C-104/75, ECLI:EU:C:1976:67 (De Peiiper). Zie voor het voorzorgsbeginsel bijvoorbeeld HvJ 5 mei 1998, zaak C-157/96, ECLI:EU:C:1998:191 (National Farmers' Union).

86. Zie bijvoorbeeld HvJ 5 februari 2004, zaak C-24/00, ECLI:EU:C:2004:70 (Commissie/Frankrijk).

87. Richtlijn (EU) 2015/1535 van het Europees Parlement en de Raad van 9 september 2015 betreffende een informatieprocedure op het gebied van technische voorschriften en regels betreffende de diensten van de informatiemaatschappij, PbEU 2015, L 241.

88. Zie bijvoorbeeld de kennisgevingen van Bulgarije 2020/258/BG (uitvoerverbod voor geneesmiddelen); Frankrijk 2020/106/F, 2020/126/F, 2020/144/F, 2020/151/F, 2020/162/F, 2020/171/F, 2020/186/F, 
wordt en de Commissie en de lidstaten de mogelijkheid krijgen de maatregelen te toetsen aan het EU-recht.

De Commissie is in een intensieve dialoog met de betrokken lidstaten maar treedt in deze crisisperiode behoedzaam op. Ze heeft de lidstaten opgeroepen om ongerechtvaardigde uitvoerverboden voor geneesmiddelen in de interne markt op te heffen, zelfs wanneer de maatregelen strikt genomen gerechtvaardigd zouden kunnen worden. ${ }^{89}$ Daarbij nodigt de Commissie de lidstaten uit tot het maken van een interessante afweging tussen het recht gebruik te maken van gerechtvaardigde beperkingen op het vrije verkeer en het tonen van onderlinge solidariteit. Het is wel de bedoeling dat alle uitvoerbeperkingen op termijn weer worden ingetrokken. ${ }^{90}$

Er zijn echter maatregelen waar de verenigbaarheid met het vrije verkeer sterk betwijfeld kan worden. In Polen hebben de autoriteiten een lijst gepubliceerd met namen van 27 bedrijven die ervan worden 'beschuldigd' melkproducten uit andere lidstaten in te voeren. ${ }^{91}$ Deze maatregel valt onder het verbod op invoerbeperkingen in de zin van artikel 34 VWEU omdat het de aankoop van uitsluitend nationale producten aanmoedigt of begunstigt. Volgens de Buy Irish-rechtspraak van het Hof van Justitie kunnen zulke 'maatregelen van gelijke werking' niet worden gerechtvaardigd voor zover ze een 'puur economisch' motief hebben. ${ }^{92}$ In Bulgarije zijn de winkels verplicht een deel van de schappen vrij te houden voor levensmiddelen van Bulgaarse oorsprong. Het Bulgaarse recht verplicht detailhandelaars om binnenlandse levensmiddelen een in het oog springende plaats in hun zaak te bieden en 90 procent van hun melk en zuivelproducten van binnenlandse producenten te kopen. Dergelijke verplichtingen beperken de uitvoer van goederen ten gunste van de nationale productie ex artikel 35 VWEU. Voorts tasten ze het recht van vestiging krachtens artikel 49 VWEU aan door de vrijheid van de detailhandelaren te beperken om over hun assortiment te beslissen, de inrichting van hun verkoopoppervlakte te bepalen en hun toeleveringsketen aan te passen. ${ }^{93} \mathrm{De}$ Commissie is er niet van overtuigd dat deze handelsbe-

2020/192/F (uitvoerverboden en -beperkingen voor verschillende producten); Tsjechië 2020/117/CZ (uitvoerverbod voor groothandel van bepaalde producten voor persoonlijke hygiëne); Duitsland 2020/127/D, 2020/116/D (verkoop van persoonlijke beschermingsmiddelen); Italië 2020/108/I (vergunningsvereisten voor de uitvoer van persoonlijke beschermingsmiddelen). De notificaties zijn te raadplegen in de TRIS databank https://ec.europa.eu/growth/tools-databases/tris/nl/.

89. Zie Mededeling van de Commissie Richtsnoeren inzake de optimale en rationele aanvoer van geneesmiddelen om tekorten tijdens de uitbraak van covid-19 te voorkomen, PbEU 2020, C 116l/1, punt 3, onder a.

90. Zie de conclusie van de Europese Raad dat 'de vaststelling van het besluit over de vergunning voor de uitvoer van persoonlijke beschermingsmiddelen moet leiden tot de volledige en doeltreffende opheffing van alle vormen van interne verboden of beperkingen'. Zie ook het stappenplan, p. 10.

91. www.gov.pl/web/rolnictwo/jedni-wspieraja-a-dla-innych-liczy-sietylko-zysk.

92. HvJ 24 november 1982, zaak C-249/81, ECLI:EU:C:1982:402 (Commissie/lerland of 'Buy Irish')

93. Zie over de kwalificatie van diensten die de detailhandel betreffen onder meer HvJ 24 maart 2011, zaak C-400/08, ECLI:EU:C:2011:172 (Commissie/Spanje). lemmeringen kunnen worden gerechtvaardigd en heeft daarom op 14 mei besloten een inbreukprocedure te starten. ${ }^{94}$

Invoer uit derde landen

De douanewetgeving van de EU biedt krachtens artikel 74-80 Verordening (EG) nr. 1186/2009 van de Raad de mogelijkheid van rechtenvrije invoer voor 'slachtoffers van rampen'. Deze wetgeving kan worden toegepast op de invoer door overheidsinstellingen of erkende filantropische of liefdadigheidsinstellingen, en wordt op verzoek van de betrokken lidstaat door de Commissie verleend. ${ }^{95}$ De Commissie heeft op 3 april besloten de verzoeken goed te keuren van de lidstaten en het VK om tijdelijk af te zien van douanerechten en btw op de invoer van medische hulpmiddelen en beschermingsmiddelen uit derde landen. De maatregel geldt voorlopig voor de periode van 30 januari tot 31 juli $2020 .{ }^{96}$

De Commissie heeft ook speciale richtsnoeren gepubliceerd om de douaneformaliteiten tijdelijk te versoepelen. Zo zijn bijvoorbeeld de formaliteiten bij de invoer van menselijke organen en beenmerg, bestemd voor transplantatie in de EU, voor het aanvragen van betalingsregelingen voor douaneschulden en voor het aantonen van de preferentiële oorsprong van goederen vereenvoudigd. ${ }^{97}$

\section{Uitvoer naar derde landen}

In de periode 15 maart tot 25 mei 2020 was voor de uitvoer van persoonlijke beschermingsmiddelen uit de EU tijdelijk een uitvoervergunning van de lidstaten nodig. EU-landen mochten alleen een vergunning afgeven als de voorraad persoonlijke beschermingsmiddelen in de EU niet in het gedrang komt. Export om humanitaire redenen was ook toegestaan. De lijst van producten werd regelmatig aangepast. ${ }^{98}$

94. Zie persbericht Europese Commissie INF/20/859, https://ec.europa.eu/ commission/presscorner/detail/nl/inf_20_859.

95. Verordening (EG) nr. $1186 / 2009$ van de Raad van 16 november 2009 betreffende de instelling van een communautaire regeling inzake douanevrijstellingen, PbEU 2019, L 324/23. Vergelijkbare bepalingen over de vrijstelling van btw voor de definitieve invoer van bepaalde goederen zijn te vinden in de btw-wetgeving van de EU. Zie art. 51-57 van Richtlijn 2009/132/EG van de Raad van 19 oktober 2009 houdende bepaling van de werkingssfeer van artikel 143, onder b) en c), van Richtlijn 2006/112/EG met betrekking tot de vrijstelling van de belasting over de toegevoegde waarde voor de definitieve invoer van bepaalde goederen, PbEU 2009, L 292/5.

96. Besluit (EU) 2020/491 van de Commissie van 3 april 2020 waarbij vrijstelling van rechten bij invoer en van btw op invoer wordt verleend voor goederen die nodig zijn om de gevolgen van de covid-19-uitbraak in 2020 te bestrijden, PbEU 2020, L 103I/1.

97. Uitvoeringsverordening (EU) 2020/633 van de Commissie van 8 mei 2020 tot vaststelling van tijdelijke maatregelen, in verband met de Covid-19-pandemie, voor de aanvaarding van elektronische kopieën van originele officiële documenten voor aanvragen voor door middel van een stelsel van invoercertificaten beheerde invoertariefcontingenten voor landbouwproducten en voor aanvragen voor invoercertificaten voor gedopte Basmati-rijst, PbEU 2020, L 148/6.

98. Zie voor de oorspronkelijke tekst Uitvoeringsverordening (EU) 2020/402 van de Commissie van 14 maart 2020 tot onderwerping van de uitvoer van bepaalde producten aan de overlegging van een uitvoervergunning C/2020/1751, PbEU 2020, L 77I/1. Door het tekort aan 


\section{Het regime van onvervalste mededinging 99}

\section{Kartels}

Om de schaarste van essentiële goederen zoals geneesmiddelen en medische hulpmiddelen het hoofd te bieden en tekorten te voorkomen, is een zekere mate van coördinatie tussen bedrijven aan de aanbodzijde noodzakelijk om de productie, het voorraadbeheer en de distributie op een zo efficiënt mogelijke manier te organiseren. Het kan bijvoorbeeld nuttig zijn afspraken te maken om te voorkomen dat alle ondernemingen zich richten op één of enkele geneesmiddelen, terwijl van andere geneesmiddelen te weinig wordt geproduceerd. Ook kan het nodig zijn dat ondernemingen commercieel gevoelige informatie over capaciteit, verkopen en voorraden (tekorten) uitwisselen.

Dergelijke onderlinge afspraken ontsnappen in normale tijden slechts bij uitzondering aan het kartelverbod van artikel 101 lid 1 VWEU. Maar in de context van de coronapandemie kan een zekere coördinatie, met passende waarborgen, duidelijke voordelen opleveren voor de samenleving waardoor wordt voldaan aan de verenigbaarheidsvereisten van artikel 101 lid 3 VWEU.

De Europese Commissie heeft op 8 april een belangrijke mededeling gepubliceerd met materiële en procedurele aanwijzingen die samenwerkende ondernemingen en hun organisaties houvast moeten geven over de verenigbaarheid van hun activiteiten met artikel 101 VWEU. ${ }^{100}$ Het 'tijdelijk kader' zal tot nader order worden toegepast.

In de mededeling worden de belangrijkste criteria toegelicht die de Commissie zal toepassen bij de beoordeling van zulke samenwerkingsprojecten. De maatregelen moeten:

1. objectief noodzakelijk zijn voor een daadwerkelijke verhoging van de output op de meest efficiënte manier om voor essentiële producten een aanbodtekort op te lossen of te voorkomen;

2. tijdelijk van aard zijn, dat wil zeggen dat zij alleen worden toegepast zolang er een tekortrisico bestaat, en

3. niet verder gaan dan strikt noodzakelijk is om het aanbodtekort op te lossen of te voorkomen.

persoonlijke beschermingsmiddelen stelde ook Nederland de uitvoer van mondkapjes, spatbrillen, handschoenen enz. naar derde landen tijdelijk afhankelijk van een exportvergunning (door de Inspectie Gezondheidszorg en Jeugd). Het verbod gold tot 26 mei, zie www.igj.nl/onderwerpen/coronavirus/nieuws/2020/05/26/ exportvergunning-persoonlijke-beschermingsmiddelengezondheidszorg-niet-meer-nodig.

99. Zie ook M.C. van Heezik, L.N.M. van Uden en L. Fiorilli, ‘De staatssteun en mededingingsregels in tijden van crisis: meer flexibiliteit voor concurrentievervalsende steunmaatregelen of afspraken?', te publiceren in het komende $\mathrm{NtEr}$-nummer.

100. Tijdelijk raamwerk voor de beoordeling van mededingingskwesties met betrekking tot samenwerking tussen bedrijven in respons op noodsituaties voortvloeiend uit de huidige covid-19-uitbraak, PbEU 2020, C 116 .
Het feit dat samenwerking wordt angemoedigd en/of gecoördineerd door een overheidsinstantie is voor de Commissie ook een relevante factor. Zulke activiteiten doen geen mededingingsbezwaren rijzen, aangezien zij ofwel geen beperking van de mededinging vormen in de zin van artikel 101 lid 1 VWEU, dan wel efficiëntieverbeteringen opleveren die zwaarder wegen dan een dergelijke beperking en dus voldoen aan de ontheffingsvoorwaarden van artikel 101 lid 3 VWEU.

Verder maakt de Commissie melding van een tijdelijke procedure die het, bij wijze van uitzondering, heeft opgezet om ondernemingen te adviseren. ${ }^{101}$ Met de tijdelijke kaderregeling maakt de comfort letter (administratieve brief) een comeback. Het instrument werd voor de hervorming van het mededingingsrecht in 2003 aangewend om bedrijven die hun overeenkomsten hadden angemeld een zekere mate van 'comfort' te geven zonder de noodzaak een (tijdrovende) formele beslissing van de Commissie af te wachten in de vorm van een negatieve verklaring of een ontheffing uit hoofde van de destijds toepasselijke Verordening nr. 17. Onder de tijdelijke kaderregeling geeft de Commissie waar nodig opnieuw comfort letters af. ${ }^{102}$

Tegelijkertijd waarschuwt de Commissie dat ze de marktontwikkelingen nauwlettend in de gaten zal houden om ondernemingen op te sporen die de huidige crisissituatie misbruiken door concurrentieverstorende afspraken te maken of hun machtspositie te misbruiken in de zin van artikel 102 VWEU. Met name bij excessieve prijsstijgingen kunnen zich dergelijke inbreuken op het EU-mededingingsrecht voordoen. In dit verband werkt de Europese Commissie samen met de nationale en internationale mededingingsautoriteiten. ${ }^{103}$

101. Daartoe heeft DG COMP een speciale webpagina gecreëerd: https:// ec.europa.eu/competition/antitrust/coronavirus.html en een speciale mailbox geopend (comp-covidantitrust@ec.europa.eu) die kan worden gebruikt om advies in te winnen.

102. De Commissie gebruikte de in de mededeling beschreven procedure direct op 8 april 2020 door het sturen van een comfort letter naar 'Medicines for Europe'. De comfort letter heeft betrekking op een vrijwillig samenwerkingsproject tussen farmaceutische producenten over een dreigend tekort aan kritieke ziekenhuisgeneesmiddelen voor de behandeling van coronapatiënten. De comfort letter is gepubliceerd op de speciale webpagina van DG COMP

103. In parallel met de totstandkoming van de 'tijdelijke kaderregeling' van de Commissie heeft het Europees samenwerkingsverband van mededingingsautoriteiten (European Competition Network, ECN) op 18 maart een gezamenlijke verklaring afgelegd waarin is aangekondigd dat de Europese mededingingsautoriteiten niet actief optreden tegen noodzakelijke en tijdelijke maatregelen die genomen worden om een tekort aan producten te voorkomen. Zie voor de verklaring van de ACM www.acm.nl/nl/publicaties/europese-mededingingsautoriteiten-entoezicht-tijdens-corona-crisis. Zie in dezelfde zin voor de verklaring van het International Competition Network (ICN) van 8 april 2020, www.internationalcompetitionnetwork.org/wp-content/uploads/ 2020/04/SG-Covid19Statement-April2020.pdf. De meest geruchtmakende zaak tot dusverre in Nederland betreft het bedrijf Roche. Daarin draait het om de beschikbaarheid van testmateriaal. Na politieke druk en een onderzoek van de ACM heeft Roche toegezegd de receptuur van het zogeheten lysisbuffer met de overheid te delen. Daarnaast werkt Roche, onder regie van de overheid, samen met producenten en laboratoria om snel tot opschaling van de productie te komen. De ACM heeft in deze zaak nauw samengewerkt met de Europese Commissie. De aanpak in Nederland kan mogelijk worden gebruikt door andere lidstaten als zich vergelijkbare leveringsproblemen voordoen. Zie het 
Voor de landbouwsector kent het EU-mededingingsrecht bijzondere bepalingen. Uit hoofde van artikel 222 Verordening (EU) nr. 1308/2013 ${ }^{104}$ is artikel 101 VWEU in beginsel van toepassing op een gemeenschappelijke marktordening voor landbouwproducten maar kan de Commissie in geval van 'ernstige marktverstoringen' tijdelijk een derogatie geven voor bepaalde handelingen (hardcore beperkingen zoals prijsmaatregelen uitgezonderd). Op 30 april heeft de Commissie van deze bevoegdheid gebruikgemaakt voor de sectoren aardappelen, bloemen en planten, en de zuivel. ${ }^{105}$

\section{Staatssteun}

In de uitzonderlijke omstandigheden die het gevolg zijn van de covid-19-uitbraak, kampen ondernemingen met een ernstig gebrek aan cashflow en inkomsten. Dit tast de economische situatie van veel gezonde ondernemingen aan en brengt hun voortbestaan in gevaar. Om de crisis het hoofd te bieden hebben alle EU-landen daarom steunmaatregelen voor bedrijven getroffen. ${ }^{106}$ Europeesrechtelijk moet die steun moet worden beoordeeld aan de hand van het staatssteunregime van artikel 107-108 VWEU. De specifieke voorwaarden daarvoor zijn vastgelegd in de 'tijdelijke kaderregeling' voor staatssteun die de Commissie op 19 maart heeft goedgekeurd $^{107}$ en op 3 april en 8 mei heeft gewijzigd, verruimd en verlengd tot (in beginsel) eind december 2020. ${ }^{108}$

Voor nationale steun - zoals loonsubsidies, gunstige leningen, overheidsgaranties of de opschorting van betaling van belastingen en sociale premies - die moet worden gekwalificeerd als in beginsel verboden staatssteun in de betekenis van artikel 107 lid $1 \mathrm{VWEU}$, is de Commissie naar eigen zeggen 'flexibeler dan ooit' ${ }^{109}$ In aanvulling op bestaande regelingen, zoals voor reddingsen herstructureringssteun die verenigbaar kunnen worden verklaard op grond van artikel 107 lid 2 onder c VWEU, voorziet de Commissie in bijkomende tijdelijke staatssteunmaatregelen die zij toelaatbaar acht overeen-

persbericht van 3 april 2020, www.acm.nl/nl/publicaties/acm-heeftvertrouwen-toezeggingen-roche-om-problemen-testmateriaal-tehelpen-oplossen.

104. Verordening (EU) nr. 1308/2013 van het Europees Parlement en de Raad van 17 december 2013 tot vaststelling van een gemeenschappelijke ordening van de markten voor landbouwproducten (...), PbEU 2013, L 347

105. Respectievelijk Uitvoeringsverordening (EU) 2020/593 voor de sector aardappelen (PbEU 2020, L 140/13); Uitvoeringsverordening (EU) 2020/594 voor de sector levende planten en producten van de bloementeelt ( $P b E U$ 2020, L 140/17) en Uitvoeringsverordening (EU) 2020/599 voor de sector melk en zuivelproducten (PbEU 2020, L 140/37).

106. Zie voor een overzicht van individuele steunverleningen die lidstaten hebben verstrekt om te voldoen aan de EU-eisen inzake transparantie over staatssteun de State Aid Transparency die te vinden is op: https:// webgate.ec.europa.eu/competition/transparency/public?lang=nl.

107. Tijdelijke kaderregeling inzake staatssteun ter ondersteuning van de economie vanwege de huidige covid-19-uitbraak (2020/C 91 I/01).

108. Zie voor de geconsolideerde versie https://ec.europa.eu/competition/ state_aid/what_is_new/TF_consolidated_version_as_ amended_3_april_and_8_may_2020_nl.pdf.

109. https://ec.europa.eu/info/live-work-travel-eu/health/coronavirusresponse/jobs-and-economy-during-coronaviruspandemic_nl\#staatssteun. komstig het zelden toegepaste artikel 107 lid 3 onder $b$ VWEU. Krachtens deze bepaling kan de Commissie steunmaatregelen verenigbaar met de interne markt verklaren om 'een ernstige verstoring in de economie van een lidstaat op te heffen'. De Commissie garandeert dat de maatregelen na aanmelding door de betrokken lidstaat zeer snel kunnen worden goedgekeurd. In de praktijk gebeurt dat doorgaans binnen twee weken. ${ }^{110}$

De regeling is in beginsel van toepassing op alle sectoren en ondernemingen, met uitzondering van de bankensector. ${ }^{111}$ De Commissie beschouwt dergelijke staatssteun als verenigbaar met de interne markt op basis van artikel 107 lid 3 onder b VWEU, wanneer in beginsel aan de volgende voorwaarden is voldaan:

1. de steun bedraagt niet meer dan 800.000 euro per onderneming in de vorm van rechtstreekse subsidies, terugbetaalbare voorschotten of belasting- of betalingsvoordelen;

2. de steun wordt verleend op grond van een regeling met een geraamd budget;

3. de steun mag worden verleend aan ondernemingen die op 31 december 2019 niet in moeilijkheden verkeerden; ${ }^{112}$

4. de steun wordt uiterlijk op 31 december 2020 verleend;

5. steun aan ondernemingen die zich toeleggen op de verwerking en de afzet van landbouwproducten wordt afhankelijk gesteld van een aantal specifieke condities ten opzichte van primaire producenten. ${ }^{113}$

Deze voorwaarden zijn zeer ruim. In twee maanden tijd keurde de Commissie voor 2.100 miljard euro aan staatssteun goed. De indrukwekkende hoeveelheid nationale budgetten die ter beschikking wordt gesteld aan het noodlijdende bedrijfsleven heeft naast instemming ook tot kritiek geleid. Eerst en vooral zet het een onvervalste mededinging binnen de interne markt onder druk - een beginsel dat juridisch is verankerd in protocol 27 van het VWEU. De massieve steun die wordt ingezet om de traditionele luchtvaartmaatschappijen van bankroet te redden heeft kritiek uitgelokt van relatieve nieuwkomers zoals Ryanair die geen beroep doen op staatssteun en daarom (niet onbegrijpelijk) wijzen op oneerlijke concurrentie. Ook zijn er klachten over het selectief steunen van bepaalde nationale sectoren (landen tuinbouw, vervoersdiensten, automobielsector, luchtvaart) ten nadele van andere bedrijfstakken die meer economische schade ondervinden (toerisme, horeca, cultuur). Daarnaast is er verontwaardiging ontstaan over

110. De besluiten van de Commissie op grond van de tijdelijke kaderregeling worden op een afzonderlijke corona-website gepubliceerd. Zie https:// ec.europa.eu/competition/state_aid/what_is_new/covid_19.html.

111. Voor de bankensector zijn sinds de financiële crisis van 2009 specifieke staatssteunregels van toepassing.

112. In de zin van de algemene groepsvrijstellingsverordening, zie art. 2 punt 18 Verordening (EU) nr. 651/2014 van de Commissie van 17 juni 2014, PbEU 2014, L 187, waarbij bepaalde categorieën steun op grond van art. 107 en 108 van het Verdrag met de interne markt verenigbaar worden verklaard.

113. Voor steun aan de primaire landbouw-, de visserij- en de aquacultuursector kent de tijdelijke kaderregeling bijzondere vereisten. Zie punt 22 en 23 van de (geconsolideerde) tijdelijke staatssteunregeling. 
staatssteun aan bedrijven die gebruikmaken van fiscale constructies om aan de nationale belastingdruk te ontkomen (in Nederland Booking.com in de eerste steunronde). Het EU-kader voor staatssteun biedt echter slechts de randvoorwaarden waarbinnen nationale overheden een zelfstandige afweging maken over de besteding van de middelen.

\section{De screening van buitenlandse investering in} strategische bedrijfstakken

De economische malaise dreigt de weerbaarheid van de Europese industrieën te verzwakken. Door kelderende aandelenkoersen kunnen de waarderingen op de kapitaalmarkten ruim onder de werkelijke waarde liggen. Daarnaast is in de context van de coronacrisis veel media-aandacht ontstaan door pogingen van buitenlandse directe investeerders om bedrijven of onderzoeksinstellingen over te nemen die gespecialiseerd zijn in de ontwikkeling en productie van schaarse goederen (bijvoorbeeld medicijnen, vaccins, beschermingsmateriaal). Een berucht voorbeeld is de door president Trump aangekondigde overname door de Verenigde Staten van het Duitse biofarmaceutisch bedrijf CureVac dat een vaccin ontwikkelt tegen het coronavirus. ${ }^{114}$

Als onderdeel van de algemene respons op de coronacrisis houdt de Commissie zich ook bezig met de screening van buitenlandse directe investeringen (BDI). Daarbij is met name de in maart 2019 vastgestelde Verordening Screening BDI ${ }^{115}$ van belang. De verordening biedt een EU-rechtelijk kader voor maatregelen tegen 'agressieve overnames' van Europese ondernemingen in essentiële sectoren door buitenlandse investeringen, met name wanneer deze investeringen gepaard gaan met overheidsparticipaties van derde landen. De verordening is van toepassing vanaf 11 oktober 2020. Op 24 maart publiceerde de Europese Commissie richtsnoeren ${ }^{116}$ waarbij de lidstaten worden aangespoord zo spoedig mogelijk een BDI-screeningsmechanisme in te voeren en, waar ze al bestaan, er volledig gebruik van te maken. In een bijlage worden daarvoor specifieke suggesties gedaan. De richtsnoeren gaan verder dan de verordening en besteden tevens aandacht aan maatregelen die kunnen worden genomen om het kapitaalverkeer te beperken wanneer zulks gerechtvaardigd is.

De Commissie kondigt in het herstelplan ook aan kritischer te willen zijn voor ondernemingen met zware subsidies van derde landen die actief zijn binnen EU-markt. Een nieuw instrument is in de makk om bijvoorbeeld op

114. Na overleg met het betrokken bedrijf maakte de Europese Commissie 80 miljoen euro steun vrij voor CureVac, in de vorm van een garantie op een lening van de Europese Investeringsbank (EIB). Zie www.nu.nl/ economie/6038080/eu-steekt-80-miljoen-euro-in-duits-bedrijf-dataan-coronavaccin-werkt.html.

115. Verordening (EU) 2019/452 van het Europees Parlement en de Raad van 19 maart 2019 tot vaststelling van een kader voor de screening van buitenlandse directe investeringen in de Unie, PbEU 2019, L 79/I1. Zie hierover J. de Kok, 'Nationale veiligheid en buitenlandse investeringen', NtEr 2019/5-6.

116. Richtsnoeren voor de lidstaten betreffende buitenlandse directe investeringen en vrij verkeer van kapitaal uit derde landen en de bescherming van de strategische activa van Europa, in afwachting van de toepassing van Verordening (EU) 2019/452, PbEU 2020, C 991/01. te treden bij overnames van bedrijven uit de EU, in aanbestedingsprocedures en in het kader van EU-financiering. Een openbare raadpleging wordt binnenkort verwacht.

\section{Economische en financiële herstelmaatregelen}

Om de financiële en economische crisis het hoofd te bieden, zet de EU een scala aan uitzonderlijke maatregelen in om de lidstaten, bedrijven en werknemers te ondersteunen. Daarbij worden bestaande programma's gecomplementeerd met coronaspecifieke initiatieven. Het voert in het kader van deze bijdrage te ver om zelfs maar een overzicht te geven van alle instrumenten. ${ }^{117}$ Hierna wordt ingegaan op een aantal onderwerpen dat verband houdt met de verdragsregimes betreffende het economisch en monetair beleid (art. 119-144 VWEU) en de financiële bepalingen van de Unie (art. 310-325 VWEU): de nationale begrotingen; de aankoop van obligaties door de Europese Centrale Bank en de voorstellen van de Commissie voor het herstelprogramma.

Voor het economisch en monetair beleid vormt artikel 119 VWEU de basis. Artikel 119 lid 1 VWEU bepaalt dat om de verdragsdoelstellingen van artikel $3 \mathrm{VWEU}$ te bereiken, het optreden van de lidstaten en de Unie gebaseerd moet zijn op nauwe coördinatie van het economisch beleid, op de interne markt en op de uitwerking van gemeenschappelijke doelstellingen, met inachtneming van het beginsel van een openmarkteconomie met vrije mededinging. Dit impliceert, aldus artikel 119 lid 3 VWEU, de naleving van de volgende grondbeginselen: stabiele prijzen, gezonde overheidsfinanciën en monetaire condities en een houdbare betalingsbalans.

EU-bijstand is dus aan een strikt formeel kader onderworpen. Enerzijds kan de Raad op grond van artikel 122 lid 1 en 2 VWEU, in een geest van solidariteit tussen de lidstaten, financiële bijstand van de Unie verlenen aan een lidstaat in geval van ernstige moeilijkheden die worden veroorzaakt door buitengewone, onbeheersbare gebeurtenissen. Maar anderzijds verbieden bijvoorbeeld artikel 123 en 124 VWEU elke vorm van kredietfaciliteit aan de lidstaten door de Europese Centrale Bank of de nationale centrale banken.

Financiële discipline is ook voorzien voor de begroting van de EU zelf. De ontvangsten en uitgaven moeten in evenwicht zijn. De Unie mag geen handelingen vaststellen die aanzienlijke gevolgen kunnen hebben voor de begroting zonder er zeker van te zijn dat die uitgaven gefinancierd kunnen worden binnen de grenzen van de eigen middelen en met inachtneming van een meerjarig financieel kader (art. 310 lid 1 en 3 VWEU).

\section{Begrotingsregels voor lidstaten}

Naast het nationale staatssteunkader heeft de EU ook het begrotingskader voor de lidstaten versoepeld. Op 20

117. Zie daarvoor de coronawebsite van de Commissie. 
maart heeft de Commissie voorgesteld om de algemene 'ontsnappingsclausule' van het Stabiliteits- en Groeipact (SGP) te activeren. ${ }^{118}$ Het SGP is er onder meer op gericht de begrotingsdiscipline van de lidstaten te waarborgen. Artikel $126 \mathrm{VWEU}$, in samenhang met protocol 12 betreffende de procedure bij buitensporige tekorten, bepaalt dat de staatsschuld van de lidstaten niet meer dan 60 procent en het jaarlijkse begrotingstekort en niet meer dan 3 procent van het bruto binnenlands product mag uitmaken. Op basis van een jaarlijks rapport van de Commissie is de Raad bevoegd maatregelen te nemen tegen lidstaten die zich niet aan deze 'Maastrichtse' begrotingsregels houden. Bij landen die de euro hebben ingevoerd, zijn die maatregelen niet beperkt tot (politieke) aanbevelingen maar kunnen ze uit hoofde van artikel 139 VWEU ook sancties zoals boetes inhouden.

De ontsnappingsclausule is vervat in twee Raadsverordeningen uit 1997 die uitwerking geven aan artikel 126 $\mathrm{VWEU}^{119}$ en passen in de algemene tendens om de strenge begrotingsregels flexibeler toe te passen. ${ }^{120}$ Door de toepassing van de ontsnappingsclausule hoeven de lidstaten zich - in beginsel - tijdelijk niet te houden aan de budgettaire beperkingen van de EU-convergentiecriteria en zullen met name de financiële dwangmiddelen thans niet worden toegepast.

Een en ander laat het systeem van de zogeheten Europese semesters onaangetast. Op grond van Verordening (EG) 1466/97 presenteren aan het begin van elk jaar alle EUlanden bij de Europese Commissie stabiliteitsprogramma's (voor de eurolanden) en convergentieprogramma's (voor de landen die niet tot de eurozone behoren) waarin ze een budgettaire doelstelling op middellange termijn formuleren. Deze programma's worden door de Commissie beoordeeld. Vervolgens geeft de Raad voor elk land afzonderlijk aanbevelingen, bijvoorbeeld om hervormingen door te voeren op de arbeidsmarkt of de woningmarkt. De aanbevelingen zijn niet bindend maar de mate van naleving ervan is relevant bij het opleggen van sancties voor het overschrijden van artikel 126 VWEU.

118. Communication from the Commission to the Council on the activation of the general escape clause of the Stability and Growth Pact. $\operatorname{COM}(2020) 123$ final, 20 maart 2020. De clausule werd in 2011 ingevoerd voor uitzonderlijke economische omstandigheden, als onderdeel van de 'Six-Pack'-hervormingen van het SGP.

119. De Commissie verwijst naar art. 5 lid 1, 6 lid 3, 9 lid 1 en 10 lid 3 Verordening (EG) $1466 / 97$ en art. 3 lid 5 en 5 lid 2 Verordening (EG) $1467 / 97$ in geval zich 'onverwachte ongunstige economische gebeurtenissen met een ernstige negatieve weerslag op de openbare financiën' voordoen. Verordening (EG) nr. 1466/97 van de Raad van 7 juli 1997 over versterking van het toezicht op begrotingssituaties en het toezicht op en de coördinatie van het economisch beleid, voorziet in toezicht op en coördinatie van het begrotingsbeleid van de EU-landen als preventieve maatregel om de begrotingsdiscipline binnen de EU te waarborgen. Verordening (EG) Nr 1467/97 van de Raad van 7 juli 1997 over de bespoediging en verduidelijking van de tenuitvoerlegging van de procedure bij buitensporige tekorten, regelt de procedure wanneer een EU-land de begrotingsdiscipline van het SGP niet respecteert.

120. Zie bijvoorbeeld ook de Mededeling van de Commissie - Optimaal benutten van de flexibiliteit binnen de bestaande regels van het stabiliteits- en groeipact (COM(2015) 12 van 13 januari 2015
In het voorjaarspakket met specifieke aanbevelingen per lidstaat dat de Commissie op 20 mei heeft gepubliceerd, wordt de focus op de korte termijn volledig gelegd op herstel in de context van de coronapandemie, zoals investeringen in de volksgezondheid en de werkgelegenheid. Op korte tot middellange termijn doet de Commissie aanbevelingen voor het realiseren van duurzame en inclusieve groei die bevorderlijk is voor de groene transitie en de digitale transformatie. ${ }^{121}$ Zoals ook uitdrukkelijk aangegeven in het herstelplan van de Commissie, is het streven dus om de begrotingsdiscipline te koppelen aan economische hervormingen en investeringen in 'groen' en 'digitaal'.

\section{Het aankoopprogramma van de Europese Centrale Bank}

De Europese Centrale Bank is actiever dan ooit met ongekende maatregelen die tot voor kort haast taboe waren, zoals het onbeperkt opkopen van obligaties. Op 18 maart heeft de raad van bestuur van het ECB het besluit genomen over een nieuw programma voor de activa-aankoop op secondaire markten (public sector purchase programme, PEPP). Het oorspronkelijke budget van 750 miljard euro is op 4 juni verhoogd naar 1.350 miljard euro. ${ }^{122}$ De raad van bestuur zal aankopen uit hoofde van PEPP beëindigen zodra hij van oordeel is dat de covid-19-crisisfase voorbij is, maar in elk geval niet voor het einde van $2020 .^{123}$

De phatever it takes-aanpak van de ECB met het massieve PEPP-noodprogramma is in landen als Nederland en Duitsland bekritiseerd met het oog op het verbod van monetaire financiering van de lidstaten in artikel 123 VWEU.

Op 5 mei 2020 heeft de eindbeslissing van het Bundesverfassungsgericht over de rechtmatigheid van het ECBopkoopprogramma dat onder de kredietcrisis werd opgezet, ${ }^{124}$ veel stof doen opwaaien. In 2017 stelde het Duitse constitutionele hof prejudiciële vragen aan het Hof van Justitie omdat het eraan twijfelde of het stimulusprogramma compatibel was met het verbod op monetaire financiering. Het Hof van Justitie deed op 11 december 2018 uitspraak over de geldigheid van Besluit 2015/774 (zoals gewijzigd) ten aanzien van een aantal monetaire verdragsbepalingen inclusief artikel 123 VWEU. In essentie kwam het Hof van Justitie tot de

121. Zie https://ec.europa.eu/commission/presscorner/detail/nl/IP_20_901. Nederland wordt onder meer aangespoord om verdere maatregelen te nemen om wat wordt genoemd 'agressieve fiscale planning' van met name de 'special purpose entities' te beteugelen. Ook krijgt Nederland als huiswerk mee om strenger op te treden tegen witwasrisico's.

122. www.ecb.europa.eu/press/pr/date/2020/html/ ecb.mp200604 a307d3429c.en.html.

123. Besluit (EU) 2020/440 van de Europese Centrale Bank van 24 maart 2020 betreffende een tijdelijk pandemie-noodaankoopprogramma, PbEU 2020, L 91/1. De verwachting is dat het ECB voor het einde van 20203.5 biljoen euro schuldpapier op de balans heeft staan - een derde van de totale uitstaande staatsschuld. Samen komt dit neer op 7,3 procent van het bbp van de eurozone.

124. Besluit (EU) 2015/774 van de Europese Centrale Bank van 4 maart 2015 inzake een programma voor de aankoop van door de publieke sector uitgegeven schuldbewijzen op secundaire markten, zoals gewijzigd. 
conclusie dat het programma voor activa-aankopen op secondaire markten niet in strijd is met het EU-recht. Het wees daarbij onder meer op de noodzaak van een ruime beoordelingsbevoegdheid voor de ECB. ${ }^{125}$

Het Duitse grondwettelijk hof stelt de uitspraak van het Hof van Justitie openlijk ter discussie. Het overweegt dat de Duitse regering en de Bundestag de Duitse grondwet hebben overtreden door na te laten stappen te ondernemen om de beslissingen van de ECB te laten toetsen op het evenredigheidsbeginsel. Weliswaar heeft het Hof van Justitie in zijn uitspraak van 11 december 2018 een ander standpunt ingenomen, maar het grondwettelijk hof acht deze uitspraak 'onbegrijpelijk', 'arbitrair' en 'ultra vires' waardoor het Hof van Justitie zich niet heeft gehouden aan zijn mandaat uit hoofde van artikel 19 lid 2 VEU. Het grondwettelijk hof ziet geen schending van het verbod op monetaire financiering van de begroting van lidstaten in de zin van artikel 123 VWEU. Het vraagt de Duitse overheid echter wel de ECB te verplichten om de evenredigheid van het opkoopprogramma van staatsobligaties aan te tonen en zo na te gaan of de economische gevolgen in verhouding staan tot de monetaire doelstellingen. De rechtsgrondslag voor deze evenredigheidstoets vindt het grondwettelijke hof in artikel 5 lid 1 en 4 VEU, in samenhang met het mandaat van de ECB dat voortvloeit uit artikel 127 lid 1 VWEU. De ECB krijgt drie maanden om het programma te verantwoorden, anders mag de Duitse centrale bank niet langer deelnemen aan het opkoopprogramma. ${ }^{126}$

Het vonnis is in EU-rechtelijke kring met ontsteltenis ontvangen. ${ }^{127}$ Zeer ongebruikelijk is dat het Hof van Justitie op de Duitse uitspraak heeft gereageerd met een vinnig persbericht waarbij het Hof van Justitie eraan herinnert dat een prejudicieel arrest voor de nationale rechter bindend is bij de beslechting van het hoofdgeding. ${ }^{128}$ Ook de voorzitster van de Europese Commissie heeft zich ondubbelzinnig achter het Hof van Justitie geschaard en publiekelijk laten weten dat een inbreukzaak wordt overwogen. ${ }^{129}$

Hoewel het grondwettelijk hof expliciet opmerkt dat het vonnis geen betrekking heeft op het 'nieuwe' PEPP ter bestrijding van de coronacrisis, is er weinig twijfel over dat ook het coronapakket van het ECB door kritische economen aan het Bundesverfassungsgericht zal worden voorgelegd, zeker omdat het nieuwe PEPP nog ruimer

125. HvJ 11 december 2018, zaak C-493/17, ECLI:EU:C:2018:1000 (Heinrich Weiss e.a.). Zie over de ruime beoordelingsmarge van het ECB ook reeds HvJ 16 juni 2015, zaak C-62/14, ECLI:EU:C:2015:400 (Gauweiler e.a.).

126. De uitspraak is beschikbaar in het Duits en het Engels. Zie www.bundesverfassungsgericht.de/SharedDocs/Pressemitteilungen/ EN/2020/bvg20-032.html.

127. Zie bijvoorbeeld M.P. Maduro, Some Preliminary Remarks on the PSPP Decision of the German Constitutional Court, https:// verfassungsblog.de/some-preliminary-remarks-on-the-pspp-decisionof-the-german-constitutional-court.

128. https://curia.europa.eu/jcms/upload/docs/application/pdf/2020-05/ cp200058nl.pdf.

129. Zie voor de verklaring https://ec.europa.eu/commission/presscorner/ detail/nl/STATEMENT_20_846. 'The final word on EU law is always spoken in Luxemburg. Nowhere else'. en omvangrijker is. Dit zal belangrijke gevolgen hebben voor de bestendigheid van het financiële systeem, de geloofwaardigheid van de rechtspraak van het Hof van Justitie en de voorrang van het EU-recht, met name in eurosceptische landen.

Herstelplannen: investeringen, kredieten en giften Tijdens de eerste maanden van de crisis hebben de EUinstellingen inclusief de Europese Investeringsbank op verschillende manieren financiële hulp verstrekt aan lidstaten en bedrijven. Daarbij wordt gebruikgemaakt van bestaande fondsen voor verschillende beleidsterreinen, zoals het Fonds voor Europese hulp aan de meest behoeftigen; het Europees Fonds voor strategische investeringen, het Europees Investeringsfonds en de Europese structuurfondsen. Voor specifieke economische sectoren zoals de landbouw zijn bijzondere fondsen ingezet. Er worden echter ook nieuwe covid-19-instrumenten ontwikkeld die tijdelijk van toepassing zijn. ${ }^{130}$ Een goed voorbeeld van zo'n tijdelijke maatregel is SURE (Support Mitigating Unemployment Risks in Emergency). Het betreft een initiatief op grond van artikel 122 VWEU om nationale arbeidsmarkten tijdens de coronacrisis te ondersteunen. SURE biedt de 27 lidstaten voor maximaal 100 miljard euro aan goedkope leningen, een bedrag dat de EU financiert door een beroep te doen op internationale kapitaalmarkten. De te financieren nationale maatregelen, die 'geacht worden de relevante grondrechtenbeginselen te eerbiedigen', moeten rechtstreeks verband houden met de invoering of uitbreiding van tijdelijke werkloosheidsregelingen of werktijdverkortingen, inclusief voor zelfstandigen. De looptijd is vanaf 1 februari 2020 tot 31 december 2022. Het SUREinitiatief is met instemming ontvangen. Op 19 mei heeft de Raad bij verordening dit leningsinstrument aanvaard. ${ }^{131}$

En dan de apotheose. Nadat Frankrijk en Duitsland op 18 mei een voorzet gaven met een gezamenlijk voorstel voor een herstelplan van 500 miljard euro en de 'vrekkige vier' aankondigden met een alternatief ontwerp te komen zonder bedrag te noemen, heeft de Commissie op 27 mei het langverwachte herstelplan gepresenteerd dat een totale 'financiële vuurkracht' van maximaal 2,39 biljoen euro moet opleveren. Het volledige pakket omvat ongeveer 50 voorstellen voor wetgeving en kent een behoorlijke dosis budget engineering.

Het plan van de Commissie bouwt voort op de bijzondere covid-19-acties waarover de Europese Raad al op 23 april een akkoord op hoofdlijnen bereikte voor in totaal 540 miljard euro. ${ }^{132}$ Het gaat hier onder meer

130. Zie voor een overzicht https://ec.europa.eu/info/live-work-travel-eu/ health/coronavirus-response/jobs-and-economy-during-coronaviruspandemic_nl\#coronavirusresponseinvestmentinitiative.

131. Verordening (EU) $2020 / 672$ van de Raad van 19 mei 2020 betreffende de instelling van een Europees instrument voor tijdelijke steun om het risico op werkloosheid te beperken in een noodtoestand (SURE) als gevolg van de covid-19-uitbraak, PbEU 2020, L 159.

132. Zie de conclusies van de voorzitter van de Europese Raad: www.consilium.europa.eu/nl/press/press-releases/2020/04/23/ conclusions-by-president-charles-michel-following-the-videoconference-with-members-of-the-european-council-on-23-april-2020. 
om eerder in deze bijdrage genoemde fondsen zoals SURE en het European Stability Mechanism Pandemic Crisis Support for Member States.

Verder doet de Commissie een herzien voorstel voor een meerjarenbegroting van 1,1 biljoen euro. Het betreft het meerjarig financieel kader voor de periode 2021-2027 zoals bedoeld in artikel 312 VWEU. Een aantal specifieke corona-instrumenten zal worden aangepast. ${ }^{133}$

Bijzonder is echter dat de Commissie daarnaast een nieuw en (voorlopig) tijdelijk noodinstrument voorstelt, Next Generation EU, voor 750 miljard euro. ${ }^{134} \mathrm{Bij}$ dit financiële instrument doen zich drie belangrijke vragen voor. ${ }^{135}$

Ten eerste, waar komt het geld vandaan? Het is de bedoeling om de fondsen vrij te maken door het plafond van de eigen middelen van de EU ex artikel 311VWEU tijdelijk te verhogen van 1,4 tot 2,0 procent van het $\mathrm{BNP}$ van de EU, waardoor de Commissie gemakkelijker geld kan lenen op de financiële markten (terug te betalen tussen 2028 en 2058). ${ }^{136}$ Bovendien kondigt de Commissie voorstellen aan voor een aantal nieuwe 'eigen middelen', onder meer op basis van het emissiehandelssysteem en een mechanisme voor koolstofcorrectie aan de grens, en een nieuwe digitale heffing op de online platforms, de 'Google tax'. Deze voorstellen zijn niet volledig nieuw maar lijken door de coronacrisis en de prioriteiten van deze Commissie op 'groen' en 'digitaal'137 nieuwe kansen te hebben om door de lidstaten geaccepteerd te worden.

Ten tweede, waarin moeten de middelen worden geïvesteerd? Het 'Recovery Instrument', gebaseerd op de bijzondere rechtsgrondslag van artikel 122 VWEU, kent drie pijlers: steun aan lidstaten voor investeringen en hervormingen; steun aan particuliere investeringen, en steun voor de volksgezondheid. Het gaat daarbij om leningen en subsidies die besteed moeten worden aan de beleidsprogramma's van de EU en de nadruk komt te liggen op investeringen in vergroening en verduurzaming; in de digitale transformatie en in het herstel van de 'resilience' van het bedrijfsleven. ${ }^{138}$

133. Zie voor de herziene voorstellen https://ec.europa.eu/info/strategy/eubudget/eu-long-term-budget/2021-2027_en. Het oorspronkelijke voorstel van de Commissie (1 biljoen euro) was onaanvaardbaar voor de 'vrekkige vier' met Nederland voorop.

134. https://ec.europa.eu/info/files/eu-budget-powering-recovery-planeurope_en.

135. Zie voor de juridische onderbouwing https://ec.europa.eu/commission/ presscorner/detail/en/qanda_20_1024.

136. Zie Gewijzigd voorstel voor een Besluit van de Raad betreffende het stelsel van eigen middelen van de Europese Unie, COM (2020) 445 def.

137. Zie voor deze prioriteiten van de Commissie https://ec.europa.eu/info/ strategy/priorities-2019-2024_nl.

138. Zie met name het voorstel van de Commissie 'for a Council Regulation establishing a European Union Recovery Instrument to support the recovery in the aftermath of the COVID-19 pandemic', COM(2020) 441 def. en bijvoorbeeld ook het voorstel voor een Verordening van het Europees Parlement en de Raad tot wijziging van Verordening (EU) nr. $1303 / 2013$ wat betreft uitzonderlijke extra middelen en uitvoeringsregelingen in het kader van de doelstelling 'investeren in groei en werkgelegenheid' om bijstand te verlenen ter bevordering van het crisisherstel in de context van de COVID-19-pandemie en ter voorbereiding van een groen, digitaal en veerkrachtig herstel van de economie (REACTEU), COM/2020/451 def.
En ten derde, waar gaat het geld naartoe? De zwaarst getroffen landen zullen de meeste steun kunnen genieten. ${ }^{139} \mathrm{Om}$ voor financiering in aanmerking te komen, moeten de lidstaten hun eigen nationale herstelplannen opstellen op basis van de in het kader van het Europese Semester aanbevolen investerings- en hervormingsprioriteiten. De Commissie is ook voorstander van de koppeling van EU-steun aan het naleven van de beginselen van de rechtsstaat in de lidstaten. ${ }^{140}$

Het voorstel is voorgelegd aan de Raad en het Europees Parlement overeenkomstig artikel 312 VWEU. De Europese Raad zal zich nu over het voorstel buigen en een politiek akkoord moeten sluiten, waarna de technische uitwerking in de Raad zal plaatsvinden en ook het Europees Parlement goedkeuring zal moeten geven. Voor budgettaire besluiten is in de Raad unanimiteit vereist. De onderhandelingen zullen met name over Next Generation EU niet gemakkelijk zijn. Het uitbreiden van de eigen middelen, de combinatie leningen (voor een derde) en subsidies (voor twee derde), de verdeling tussen de lidstaten en de koppeling van financiële steun aan nationale hervormingen zijn, zoals bekend, onderwerp van stevige politieke discussie.

\section{Slotbeschouwingen}

Reageert de EU adequaat op het covid-19-virus? Wat zijn de gevolgen van de crisis voor Europa? Zolang de pandemie nog heerst, is het te vroeg om die vragen te beantwoorden. De volgende opmerkingen zijn echter alvast te maken.

$\mathrm{Na}$ de uitbraak van covid-19 werden de EU-instellingen geconfronteerd met nationale crisismaatregelen die erop gericht waren de verspreiding van het virus te onderdrukken. Volksgezondheid is in de eerste plaats een bevoegdheid van de lidstaten en door de omvang van de crisis mag het niet verbazen dat het even heeft geduurd voordat de EU haar coördineerde en complementaire rol bij de bestrijding van het covid-19-virus volledig heeft kunnen uitoefenen.

Het overzicht toont aan dat sinds begin maart 2020 vooral de Europese Commissie, met instemming van de Raad en het Europees Parlement, een omvangrijk pakket initiatieven heeft genomen. De Commissie lanceert hulpacties en faciliteert de uitwisseling van technische expertise over het virus met de lidstaten. Die samenwerking leidt bijvoorbeeld tot de ontwikkeling van een corona-app die ook over de grens functioneert en de gezamenlijke inkoop van essentiële goederen zoals vaccins en andere medicijnen. Met het oog op covid-19 relevante

139. Zie voor een overzicht van de voorgestelde verdeling tussen de lidstaten https://ec.europa.eu/info/sites/info/files/3pillars_factsheet.pdf.

140. Zie voorstel voor een Verordening van het Europees Parlement en de Raad inzake de bescherming van de begroting van de Unie in geval van fundamentele tekortkomingen op het gebied van de rechtsstaat in de lidstaten, COM/2018/324 final van 2 mei 2018. Het voorstel is gebaseerd op art. 322 VWEU dat de EU-wetgever bevoegdheid geeft om regels vast te stellen voor de manier waarop controle en verantwoording wordt afgelegd voor begrotingen. 
onderwerpen verduidelijkt de Commissie bestaande EU-regelgeving op het gebied van onder meer grenscontroles, het vrije goederenverkeer en de consumentenbescherming De kaders waaronder crisiskartels zijn toegestaan en lidstaten steun kunnen verlenen zijn aangegeven en er vindt toezicht plaats op de wijze waarop dat mededingingsrecht wordt toegepast. Langzamerhand neemt de EU ook het initiatief in handen om te werken aan het herstel van de economie.

Bij deze initiatieven wordt veelvuldig gebruikgemaakt van niet-bindende aanbevelingen en 'richtsnoeren' zelfs waar de bevoegdheden van de EU beperkt zijn maar een Europese aanpak voor de hand ligt, zoals bij hygiëneprotocollen in hotels en luchthavens. Bij thema's die de interne markt en het EU-mededingingsregime betreffen, is soft law niet altijd vrijblijvend. De Commissie waarschuwt dat lidstaten en ondernemingen die de aanwijzingen niet volgen kunnen rekenen op sancties. $\mathrm{Er}$ is in deze moeilijke tijden begrip voor uitzonderlijke maatregelen maar deze moeten niettemin passen binnen het bestaande rechtskader. De aanbevelingen en richtsnoeren over onder meer grenscontroles, markttoegang van schaarse producten, samenwerking tussen bedrijven en de steunmaatregelen zijn dan met name bedoeld om de flexibiliteit in de huidige EU-wetgeving binnen de covid-19-context aan te geven en een basis te vormen voor dialoog. Het aantal inbreukzaken dat de Commissie wegens covid-19 heeft gestart, blijkt tot dusverre beperkt tot een enkele zaak tegen een lidstaat over het vrije goederenverkeer.

De meeste EU-noodmaatregelen hebben uit de aard van de zaak een tijdelijk karakter, hoewel de 'temporele werking' verschilt per onderwerp. Een deel van de richtsnoeren blijft ook in de toekomst relevant. Dat geldt bijvoorbeeld voor de condities waaronder tijdelijke grenscontroles kunnen worden ingevoerd, en de verduidelijking van de EU-productwetgeving.

In deze tijden van zware crisis zijn EU-maatregelen om op korte termijn de Europese bedrijven en nationale begrotingen te ondersteunen onvermijdelijk. Voorstellen worden gedaan binnen de flexibiliteit die het huidige verdragsregime voor het economisch en monetair beleid en de begroting biedt. Na enige aarzeling over gezamenlijke schulden kan die aanpak zelfs van Nederlandse kant in toenemende mate rekenen op steun - mits in combinatie met hervormingen. Het verdrag geeft daarvoor mogelijkheden, zoals het systeem van de Europese semesters. Hoewel de crisis een enorme klap betekent voor de economie, biedt het ook kansen voor strategische investeringen in vergroening en duurzaamheid, en in de digitale infrastructuur zoals 5G. De Commissie zet in het herstelplan zwaar op deze prioriteiten in. Ook worden verdere stappen gezet naar nieuwe eigen middelen die moeten komen van 'vervuilers' en online platforms.

Zeker is dat covid-19 de wereld en dus ook Europa op veel gebieden ingrijpend verandert. De coronacrisis legt fundamentele uitdagingen bloot voor de toekomst van de EU (zonder het VK).
Ondanks het feit dat concrete inbreuken op het EUrecht vooralsnog beperkt zijn, staat de integriteit van de interne markt met een vrij verkeer en een onvervalst mededingingsregime onder druk. Voorbeelden zijn de nationale regelingen om tekorten aan schaarse goederen tegen te gaan, de flexibiliteit bij de uitlegging van de EU-wetgeving en de onvergelijkbare niveaus van nationale staatssteun. De verschillen in hoogte en intensiteit van de steun roept bijvoorbeeld de vraag op of de economisch zwakkere landen niet onevenredig worden achtergesteld bij de rijkere lidstaten. ${ }^{141}$ Dit is geen nieuwe kwestie (welvarende landen hebben per definitie meer financieel vermogen) maar de ongeziene bedragen die worden vrijgemaakt in combinatie met de politieke clash over de hoogte en verdeling van het Europese herstelpakket geven een nieuwe draai aan de discussie. De Commissie is zich van deze kritiek bewust en wijst er in het herstelplan op dat de tijdelijke flexibiliteit van het mededingingsregime niet moet leiden tot een structurele fragmentatie van de interne markt. Het feitelijke ongelijke speelveld rechtvaardigt in haar ogen ook dat bij de EU-steun aan de lidstaten rekening wordt gehouden met nationale draagkracht.

De coronapandemie heeft tevens een geopolitieke dimensie. Lange internationale aanvoerketens en het outsourcen van strategische industrieën buiten Europa zijn niet ideaal in tijden van crisis waarin de lokale of regionale beschikbaarheid van essentiële producten van levensbelang is. Investeringen in groen en digitaal is ook noodzakelijk om minder afhankelijk te worden van de VS en China. Een nieuwe balans tussen vrijhandel en bescherming van legitieme belangen is nodig. De Commissie zegt in haar herstelplan een 'model van open strategische autonomie' na te streven. ${ }^{142}$ Het BDI-instrument en de richtsnoeren van de Commissie tegen oneerlijke praktijken en misbruik om EU-bedrijven via staatsparticipaties af te schermen tegen (Chinese) overnamedreiging zijn voorbeelden van deze nieuwe aanpak.

De beginselen van de rechtsstaat stonden in een aantal lidstaten al op de tocht en zijn door de noodsituaties vanwege corona alleen maar meer in de verdrukking geraakt, zoals de ontwikkelingen in met name Hongarije laten zien. ${ }^{143}$ Desinformatie neemt toe en extreme politieke posities kunnen in bepaalde landen rekenen op veel bijval. Het voorstel om EU-steun afhankelijk te maken van het respecteren van de rechtsstaat biedt perspectief. Daarbij zal in eerste instantie de Commissie en in de context van artikel 7 VEU ook de Raad - moed moeten tonen om ook daadwerkelijk maatregelen te

141. Op 18 mei verklaarde vicepresident Vestager tegenover de Europese pers dat Duitsland goed is voor 47 procent van alle goedgekeurde staatssteun, op grote afstand gevolgd door Italië (18 procent), Frankrijk (16 procent), Spanje (4 procent) en het VK (4 procent). El País 26 mei 2020.

142. Zie het herstelplan van 27 mei 2020, p. 15.

143. De regering-Orbán regeert per decreet en wordt ervan beschuldigd beperkende maatregelen te nemen die geen verband houden met de pandemie. Zie voor de oproep van het EP tot sancties www.europarl.europa.eu/news/nl/press-room/20200512IPR78917/ hongaarse-covid-19-noodmaatregelen-ep-wil-sancties-en-stopzettenvan-betalingen. 
nemen tegen lidstaten die onwillig zijn de fundamentele rechten te respecteren. In dit verband kan ook het vonnis van het Bundesverfassungsgericht worden vermeld, volgens sommigen een ontoelaatbare aanval op de legitimiteit van de EU.

Tot slot. Bij een pandemie gaan de grenzen dicht en prevaleert, zo blijkt, het nationale belang. Het vertrouwen in Europa en andere lidstaten is in landen als Italië en Spanje zorgwekkend gedaald, deels door een vermeend gebrek aan solidariteit. De Commissie heeft uitdrukkelijk aangegeven dat van de lidstaten wordt verwacht dat zij de volksgezondheid in de geest van Europese solidariteit beschermen. ${ }^{144}$ Van een collectieve en samenhangende aanpak van de economische crisis profiteert uiteindelijk iedereen binnen de interne markt. ${ }^{145}$ Het overzicht in deze bijdrage bewijst dat solidariteit en samenwerking binnen EU-verband wel degelijk aanwezig is. Er zal echter meer moeten gebeuren om dat voor de burgers ook zichtbaar te maken. 